\title{
Passives and impersonals ${ }^{1}$
}

\author{
JAMES P. BLEVINS \\ University of Cambridge
}

(Received 3I August 200I; revised 28 February 2003)

This paper argues that the term 'passive' has been systematically misapplied to a class of impersonal constructions that suppress the realization of a syntactic subject. The reclassification of these constructions highlights a typological contrast between two types of verbal diathesis and clarifies the status of putative 'passives of unaccusatives' and 'transitive passives' in Balto-Finnic and Balto-Slavic. Impersonal verb forms differ from passives in two key respects: they are insensitive to the argument structure of a verb and can be formed from unergatives or unaccusatives, and they may retain direct objects. As with other subjectless forms of personal verbs, there is a strong tendency to interpret the suppressed subject of an impersonal as an indefinite human agent. Hence impersonalization is often felicitious only for verbs that select human subjects.

\section{INTRODUCTION}

Passive and impersonal constructions have a strikingly different status in current theoretical and descriptive studies. All contemporary approaches recognize passive constructions, and provide some means of relating their properties to those of corresponding actives. Any framework that did not would be considered fundamentally deficient or incomplete. Many descriptive grammars likewise apply a broad notion of 'passive' to any alternation that inhibits the expression of the subject. In contrast, impersonal constructions often remain implicit in language descriptions and have, until recently, been almost entirely neglected in theoretical work. This omission is not accidental, as most frameworks expressly exclude the possibility of subjectless constructions. HPSG is one of the few that appears relatively agnostic on this score. Most other approaches incorporate some subject-legislating constraint, whether expressed as the 'Extended Projection Principle' of

[I] This paper grew out of a talk presented at Stanford in I996, while I was a visitor at the Center for the Study of Language and Information. I am grateful to CSLI for their hospitality and to Joan Bresnan and Ivan Sag for their comments on early versions of the paper. Many improvements in the present version are due to discussions and/or correspondence with Farrell Ackerman, Loren Billings, Len Babby, Steve Hewitt, Anna Kibort, John Moore, James Lavine, Peter Matthews, Andrew Spencer and Reeli Torn; the suggestions of Bob Borsley and an anonymous $J L$ referee; and feedback from audiences at Stanford, the University of Massachusetts, Princeton University, and the University of Surrey. 
Chomsky (I982), the 'Final I Law' of Perlmutter \& Postal (I983b), or the 'Subject Condition' of Bresnan \& Kanerva (1989).

Taken together, the near-universal recognition of passives and the corresponding neglect of impersonals introduce a tacit descriptive bias in favor of passives. Constructions that occupy the communicative niche associated with the passive are often treated as passives, even when they differ from passives in respects that are clearly noted in the traditional, specialist, and pedagogical literature.

This paper identifies two significant, and wholly undesirable, consequences of this descriptive bias. The first is a misanalysis of individual constructions, illustrated by the 'passive' treatment of 'impersonal voice' forms in BaltoFinnic, and 'autonomous' forms in Celtic. The second consequence is an extended notion of 'passive' that subsumes formally distinct subconstructions and therefore exhibits variation that confounds attempts to impose substantive constraints. The conclusions drawn from 'impersonal passives' in Balto-Slavic illustrate the theoretical effects of this misclassification. A passive analysis of synchronically impersonal forms in no/to in Ukrainian has fostered the belief that 'transitive' subjectless passive constructions may retain structural accusative objects (Sobin 1985). A similar misclassification of malta forms in Lithuanian underlies claims that passives may be formed from what Perlmutter (1978) calls 'initially unaccusative' verbs (Nerbonne I982; Timberlake 1982).

Since these types of patterns violate various laws proposed within relational grammar (RG; Perlmutter \& Postal I984b), they have been interpreted as refuting relational analyses of the passive. Yet the recognition of 'transitive' and 'unaccusative' passives does not yield any new insights or generalizations. On the contrary, reclassifying differences between separate subconstructions as variation within a heterogeneous passive 'macroconstruction' simply raises a host of new problems. No account that admits an expanded class of passives identifies any non-diacritic properties of a language or construction inventory that correlate with the possibility of forming unaccusative or transitive passives. ${ }^{2}$ Nor does any account offer a principled basis for excluding such passives in the languages that disallow them.

This paper argues that there can be no characterization of the languages that permit unaccusative and transitive passives because, as claimed in RG accounts, there are no such languages. There are no passives of unaccusatives because passivization deletes 'logical' subject arguments, and the lack of a logical subject argument is precisely what defines unaccusatives as a class. There are no subjectless transitive passives, because the failure to identify any 'structural' argument as a 'surface' subject indicates that the

[2] See Baker et al. (1989) and Bresnan \& Kanerva (1989) for the most clearly articulated accounts of this sort. 
logical subject has been suppressed and not deleted. Subjectless forms of unaccusative verbs are dedicated impersonals, as are subjectless verb forms with structural objects.

The traditional contrast between 'logical' and 'surface' subjects permits a description of passive and impersonal constructions that abstracts away from the formal representation of subjects. The analyses in section 3 define logical subjects (and the 'initial' subjects of RG) in terms of the subject demands of an active verb stem. The notion of a 'surface' (or 'final') subject is likewise represented by the subject demands of an inflected verb. Both notions of 'subject' thus refer to the lexical argument structure of a verb, not to the expressions that satisfy those demands in a syntactic context. However, for the purpose of distinguishing passive from impersonal constructions, one could equally well adopt other, more syntactic, definitions. The key contrast is not between lexical and syntactic views of valence alternations, but rather between valence-reducing and valence-preserving processes. Whereas passivization detransitivizes a verb by deleting its logical subject, impersonalization preserves transitivity, and merely inhibits the syntactic realization of a surface subject. The argument structure of a passive verb thus contains one less term argument than that of an active verb, while an impersonalized verb maintains the same number of terms as the corresponding personal forms.

The difference between deleting a logical subject and suppressing a surface subject is masked to some degree in intransitives, since the result is subjectless in either case. However, transitives clearly bring out the contrast between these operations. Passivization of a basic transitive yields a derived intransitive, whose surface subject corresponds to the object of the transitive. Impersonalization, in contrast, always defines a subjectless form, irrespective of the argument structure of its input. Hence impersonal forms of transitive verbs retain grammatical objects. If a language permits object cases to be expressed in constructions without an expressed nominative, the object may occur in the accusative (as in Polish or Ukrainian), or in the partitive (as in Balto-Finnic). In other languages, the object may occur in the nominative or alternate between nominative and accusative, as in Lithuanian (Ambrazas 1997: 66I) or varieties of Slovene and Serbo-Croatian (Browne 1993: 333).

The difference between deletion and suppression is reflected in other ways. The suppressed subject in an impersonal construction can sometimes serve as an antecedent for a reflexive pronoun, whereas the deleted subject of a passive never can. Impersonals also tend to retain an active interpretation, associated with an indefinite, canonically human, agent. A similar interpretation is frequently associated with subjectless passives, as well as with subjectless 3 rd plural forms in many languages. Hence the implication of human agency does not reflect a grammatical feature of impersonal constructions, but rather a default interpretation assigned to subjectless forms of personal verbs. Nevertheless, this interpretive convention largely restricts 
impersonalization to verbs whose subject can be construed as human. Thus, in Estonian, impersonalization applies freely to unaccusative verbs like OLEMA 'to be', but never to non-transitives like коIтMA 'to dawn', nonanimate intransitives like AEGUMA 'to expire', or even to non-human intransitives like HAUKUMA 'to bark' (Torn 2002: 95). ${ }^{3}$

The fact that passivization targets logical subjects prevents it from applying to unaccusative verbs, on the usual assumption that the surface subject of an unaccusative does not correspond to a 'deep' or logical subject. Yet because passivization does not directly constrain surface subjects, it may feed impersonalization in languages such as Irish (Noonan 1994) and Polish (Kibort 2000). Both languages allow the impersonalization of a passivized transitive (but not of a passivized intransitive, since they disallow the impersonalization of non-transitives in general). The converse derivation is, however, excluded in principle, and appears to be unattested. Since impersonalization defines a subjectless output, it should never feed passivization, which requires a logical subject.

The contrast between subject-deleting passivization and subjectsuppressing impersonalization yields the construction inventory in (I). Impersonals have transitive and intransitive subtypes, determined by their input, whereas passives fall into personal and subjectless subclasses.

(1)

\begin{tabular}{|c|c|c|c|c|}
\hline \multicolumn{2}{|c|}{ VERB TYPE } & IMPERSONAL & PASSIVE & IMPERSONALIZED PASSIVE \\
\hline \multirow[t]{2}{*}{ Transitive } & Unergative & \multirow[t]{2}{*}{ Transitive } & Personal & Intransitive \\
\hline & Unaccusative & & - & - \\
\hline \multirow[t]{2}{*}{ Intransitive } & Unergative & \multirow[t]{2}{*}{ Intransitive } & Subjectless & - \\
\hline & Unaccusative & & - & - \\
\hline
\end{tabular}

The body of this paper provides a more detailed description and analysis of the construction types in (I). The mainly descriptive discussion in section 2 first clarifies the core differences between passive and impersonal constructions and reviews some of the variation within the class of impersonals. Section 3 then suggests how a lexicalist analysis can rehabilitate relational accounts of the passive and also capture the distinctive morphosyntactic properties of impersonal constructions.

\section{PASSIVE AND IMPERSONAL CONSTRUCTIONS}

To clarify the contrast between passives and impersonals, it is useful to examine canonical examples of each construction. The properties of German passives are summarized in section 2.I, followed in section 2.2 by

[3] Following the conventions in Matthews (199I), lexemes are placed in SMALl CAPITALS, and forms of lexemes in italics. 
a description of impersonal patterns in Balto-Finnic. Section 2.3 considers a class of historically neuter forms in Balto-Slavic, and argues that these are synchronically deponent, in the sense that they are 'passive in form' but predominantly 'active in meaning' (cf. Gildersleeve \& Lodge I895). Sections 2.4 and 2.5 conclude with a discussion of 'autonomous' and reflexive impersonals.

\section{I Passives in German}

Personal passives are usually regarded as 'the core case of passive' Chomsky (198I), on the grounds that they exhibit all of the properties associated with the passive construction. The German example in (2b) illustrates a canonical personal passive. The subject of the active (2a) corresponds to the optional oblique in the passive (2b). The accusative object in (2a) likewise corresponds to the subject in (2b), where it occurs in the nominative case and triggers verbal agreement. The logical subject is thus said to be 'demoted' to an oblique, whereas the logical object is 'promoted' to subject.

(2) (a) Der Beamte hat den Vorschlag abgelehnt. the.NOM official has the.ACC proposal rejected 'The official has rejected the proposal.'

(b) Der Vorschlag wurde (vom Beamten) abgelehnt. the.NOM proposal was by +the.DAT official rejected 'The proposal was rejected by the official.'

Debates about the universal grammatical properties of passives turn, for the most part, on which properties of personal passives are taken to be definitional, and which are merely characteristic. One possibility is to regard subject demotion as the primary effect of passivization, with promotion as an opportunistic side-effect. Alternatively, promotion can be identified as the main effect, which has as a consequence the demotion of the logical subject. Since personal passives exhibit both demotion and promotion, they provide no basis for adjudicating between these choices. Subjectless passives have thus played a pivotal role in debates because they exhibit the same form variation and subject demotion as personal passives, but show no evidence of promotion. As Comrie (1977) observes, any passive rule that is meant to apply to personal passives like (2) and to subjectless passives like (3) should demote subjects, not promote objects, since there is no obvious object to promote in (3a).

(3) (a) Viele Leute haben in der Küche geraucht. many people have in the kitchen smoked

'Many people have smoked in the kitchen.'

(b) In der Küche wurde (von vielen Leuten) geraucht. in the kitchen was.3SG by many people smoked 'There was smoking by many people in the kitchen.' 
Passivization of a verb that governs an 'oblique' case also yields a subjectless output in German. Since datives are not admissible subjects in German, the dative object of the active participle in (4a) 'remains' an object of the passive participle in (4b), and does not trigger verb agreement. Neither promotion nor subjectlessness is directly effected by passivization in ( $3 \mathrm{~b}$ ) and (4b). Rather, subjectlessness is due to the fact that (3a) and (4a) do not contain an 'advanceable' non-subject.

(4) (a) Die Lehrerin hat diesen Kindern schon geholfen. the.NOM teacher has these.DAT children.DAT already helped 'The teacher has already helped the children.'

(b) Diesen Kindern wurde (von der Lehrerin) schon geholfen. these.DAT children.DAT was by the teacher already helped 'These children were already helped by the teacher.'

Comrie's claim that subject demotion is the primary effect of passivization echoes a traditional subject-oriented perspective. This claim is contested in $\mathrm{RG}$, as it entails a treatment of the passive in which demotion of the logical subject occurs 'spontaneously', rather than as a consequence of an antecedent promotion. Hence the RG literature standardizes instead on alternatives in which subjectless passives involve advancement of a demotioninducing 'dummy' nominal. The recourse to dummies, and the retention of the Motivated Chômage Law which requires them, rests ultimately on the intuition that passives are intrinsically promotional. ${ }^{4}$ Yet in the same way that an Indo-European bias underlies the 'passive' classification of Balto-Finnic impersonals, the influence of English can perhaps be discerned in attempts to extend a promotional analysis to subjectless passive constructions.

\section{I.I The Unaccusative Hypothesis}

Comrie's subject-oriented analysis not only applies to unergative intransitives like RAUCHEN in (3), but also offers a straightforward account for the observation that unaccusative verbs do not passivize. The unacceptability of unaccusative geblieben in (5b) illustrates this restriction.

(5) (a) Viele Leute sind in der Küche geblieben. many people are in the kitchen remained 'Many people have remained in the kitchen.'

(b) *In der Küche wurde (von vielen Leuten) geblieben. in the kitchen was.3SG (by many people) remained '*There was remaining by many people in the kitchen.'

[4] As a referee notes, the interaction of Burzio's generalization (Burzio 1986) with a standard version of the Case filter (Chomsky 198I) has an effect within transformational accounts similar to that of the Motivated Chômage Law. 
The Unaccusative Hypothesis (UH) distinguishes unergatives like RAUCHEN from unaccusatives like BLEIBEN in terms of their initial argument structure. As formulated in Perlmutter \& Postal (I983a: 69), the hypothesis holds that "many intransitive clauses have an initial direct object but no subject'. Such clauses, termed 'initially unaccusative', contrast with 'initially unergative' clauses, which do contain a logical subject. ${ }^{5}$ Now if unaccusatives are treated as lacking logical subjects, and if passivization is defined as demoting logical subjects, it follows immediately that ' $\mathrm{n}] \mathrm{o}$ impersonal Passive clause in any language can be based on an unaccusative predicate' (Perlmutter \& Postal 1984a: I07). A passive rule that demotes logical subjects will simply fail to apply to verbs without logical subjects. Since the lack of a logical subject is exactly what defines unaccusatives as a class, it follows that they should never passivize. A subject-oriented rule is thus intrinsically sensitive to the variation in argument structure posited by the UH between unergative and unaccusative intransitives.

A demotion-based analysis also applies to transitive unaccusatives, such as DAUERN in (6).

(6) (a) Die Tagung hat eine Woche gedauert. the meeting has one week lasted 'The meeting lasted a week.'

(b) *Eine Woche wurde (von der Tagung) gedauert. one week was by the meeting lasted '*A week was lasted by the meeting.'

If the initial argument structure of DAUERN contains two non-subject arguments, a subject-oriented demotion rule will again fail to apply. The parallels between this class of verbs and intransitives like BLEIBEN also suggest that attempts to block (6b) by focusing on the properties of the object are misdirected, except insofar as these properties reflect an initially unaccusative argument structure. ${ }^{6}$

In contrast, nothing prevents a promotional rule from applying to unaccusatives, especially given the RG assumption that unaccusatives specify logical objects. Since an object advancement analysis does not directly distinguish verbs that specify logical subjects from those that lack subjects, RG accounts adopt an indirect strategy to exclude passives of unaccusatives. Perlmutter \& Postal (I984a: 84) propose The I-Advancement Exclusiveness

[5] Though, as noted in the introduction, it will suffice if unaccusatives are defined as merely failing to specify a subject.

[6] This analysis also suggests that the difference between unergative and unaccusative passives in English may be masked by a blanket prohibition against impersonal constructions in general. Since the passive of any intransitive verb will be subjectless, and hence unacceptable, no intransitive verb may passivize. Yet developing this account in greater detail would carry us too far afield, requiring a reexamination of pleonastic strategies and transitivity constraints on passives. 
Law (IAEX), which stipulates that there can be at most one advancement to subject in a clause. The IAEX prevents the passivization of unaccusatives, on the RG assumption that the final subjects of initially unaccusative verbs are promoted by a process of object-to-subject advancement. Given the Motivated Chômage Law, these derived subjects can only be demoted by the advancement of another argument to subject. But the advancement of any other argument violates the IAEX. Hence the passive rule cannot apply.

Whatever the merits of this kind of solution within $R G$, it is clear that the need for a dedicated constraint like the IAEX must be counted among the descriptive costs of a promotional theory of the passive. More significantly, a striking correlation between verb classes and voice is utterly obscured. Whereas a subject-oriented account can directly exploit the difference in argument structure between unergative and unaccusative verbs, $\mathrm{RG}$ must constrain the number of advancements to subject.

\section{I.2 The interpretation of subjectless forms}

RG accounts nevertheless express a number of useful intuitions about passive constructions. The most basic is that passivization is sensitive to grammatical relations, not merely to thematic or semantic prominence. Although most $\mathrm{RG}$ accounts fail to identify subject demotion as the defining property of passivization, they do recognize demotion as a characteristic effect. Even the RG intuition that objects are somehow essential to the passive construction can be recast as the conjecture that no language contains a passive strategy that solely defines subjectless passives. RG accounts do not state things in quite this way, in part because they tend to misclassify Celtic autonomous constructions as subjectless impersonals (Perlmutter \& Postal I984a: IIo). Once this sort of misanalysis is corrected (for example, along the lines suggested in section 2.4 below), it is not clear that one is left with any genuinely passive constructions that only produce a subjectless output. The interpretive overlap between impersonal constructions and subjectless passives suggest an explanation for this gap.

It is often observed that subjectless passives have an 'indefinite' or 'human' or 'agentive' interpretation. The description of German passives in Durrell (1996: 297) states this restriction clearly:

The werden-passive can be used without a subject to denote an activity in general ... The agent is unspecified, so that there is no indication of who is performing the action.

A subjectless passive can be formed from any verb which expresses an activity by an agent, whether the verb is transitive or intransitive [emphasis added, JPB].

The human reference that is to some degree implicit in the notion of an agent is reinforced by the human relative pronoun in this passage, as well as 
by the use of 'they' and 'men' in the glosses that Durrell (1996: 297) assigns to subjectless passives in German. The fact that this interpretation is also characteristic of impersonal constructions suggests that a uniform interpretation is associated with subjectless forms of personal verbs. That is, a subjectless form of personal verb is conventionally interpreted as referring to an indefinite human agent, irrespective of the source of its subjectlessness. ${ }^{7}$

The interpretive parallels between subjectless passives and impersonal constructions account in large part for the pervasive misclassification of impersonals. However, these parallels also constrain the range of possible passive systems. One would surely not expect a passive process that defined only subjectless constructions to be stable. The output of such a process would be nearly indistinguishable from the output of impersonalization. Consequently, a passive system with no personal constructions would be highly susceptible to reinterpretation as an impersonal system. The 'deponent participles' of Balto-Slavic clearly show that historically passive forms may evolve into impersonals, and this development would be almost inevitable in a system consisting exclusively of subjectless passives.

\section{I.3 Summary}

The present account follows $\mathrm{RG}$ in regarding passivization as a relationchanging operation, but follows Comrie (1977) in treating subject demotion rather than object advancement as basic. Strictly speaking, 'demotion' is not a unitary operation, but rather reflects two processes: the deletion of a logical subject, and the realization of the associated semantic role by an oblique. Object advancement in personal passives is likewise a purely 'opportunistic' side-effect of the deletion of the logical subject.

On this essentially conservative view, passive constructions are a morphosyntactic class, defined in terms of their argument structure, not their meaning, function, use, or morphotactic properties. This is not to dispute that the characteristic interpretation assigned to passive constructions may make them suitable for a range of communicative functions, including the backgrounding of logical subjects, or the foregrounding of non-subjects. Nor does it exclude the possibility that the passives in a language may comprise a coherent form class, with consistent patterns of stem selection or inflectional exponence. However, from the traditional perspective adopted in relational accounts, these semantic and formal traits are merely characteristic properties of passives, and do not enter into the definition of passive constructions. Hence there is no inconsistency in including, for example, the ' $3 \mathrm{pl}$ form of the verb' among the 'ways of expressing passive actions'

[7] Precisely the same interpretation is assigned to $3 \mathrm{pl}$ forms in many languages. As Wade (I992: 325) remarks in connection with Russian ' $[t]$ the use of a third person plural ... emphasizes the involvement of a human agent'. 
(Pugh \& Press 1999: 250) in many Slavic languages, even though these forms are not morphosyntactically passive. The existence of active 'deponent' verbs that pattern morphotactically with passives is likewise unproblematic.

The distinction between morphosyntactic passive constructions and the broader class of constructions that may be 'passive in meaning' or 'passive in form' highlights the equivocations that often underlie challenges to relational accounts. In particular, the Balto-Slavic constructions that have been identified as 'passives of unaccusatives' (Timberlake 1982) or 'transitive passives' (Sobin 1985) are residually 'passive in form' and even 'passive in meaning' but are not morphosyntactically passive. This contrast is important because the universals proposed in $\mathrm{RG}$ accounts are meant to apply to morphosyntactic passives, not to constructions that pattern with passives in meaning or form.

\subsection{Impersonal actives in Balto-Finnic}

Whereas subjectlessness is also a purely contingent property of passive constructions, it is the defining property of impersonals. The grammatical reflexes of this difference clearly distinguish impersonals from passives, despite the close functional and formal parallels between the two constructions. There can be no promotion to subject in a subjectless construction. Hence impersonals of transitive verbs may retain structural objects. Depending on the case conventions of a language, these objects may occur in objective cases, such as accusative or partitive. Impersonals thus pattern syntactically with synthetic verb forms that incorporate a subject argument. However, the suppressed subject of an impersonal canonically receives the indefinite human interpretation characteristically associated with subjectless forms of personal verbs. This interpretation gives rise to terms such as 'indefinite' (Shore I988) or 'ambipersonal suppressive' (Tommola 1997), to distinguish impersonal forms from weather verbs and other types of impersonal verbs, which lack, rather than suppress, logical subjects.

Impersonal constructions in Balto-Finnic can be said to be canonical, in that they combine morphosyntactic subject suppression with an indefinite human interpretation. Hence this class of morphosyntactic impersonals are also 'impersonal in meaning', ${ }^{8}$ Although references to 'passives' are not uncommon in Balto-Finnic grammars, this ultimately functional classification is meant to highlight the role of these constructions in a language. This classification is, however, usually accompanied by more fine-grained descriptions that identify the constructions in question as impersonal. For this reason, it is instructive to review descriptions of meaning and use-drawn

[8] They are, as well, 'impersonal in form', given that periphrastic passives in a language like Estonian are the innovations, formed from the auxiliary OLEMA and the perfect impersonal participle in tud (Pihlak I993; Rajandi I999). 
from both the specialist and pedagogical literatures-to complement examples that illustrate form and distribution.

\subsection{Estonian}

An impersonal 'voice' is a distinctive feature of Balto-Finnic, which is often explicitly contrasted with the passive voice of neighboring Indo-European languages. ${ }^{9}$ As Viitso (1998) notes, an impersonal voice can be reconstructed for proto-Fennic, whereas the passive in Estonian is an innovation:

Corresponding to the six forms that make up the personal voice there was an impersonal voice in proto-Fennic ... Such impersonalization is still possible in all tenses and moods in all Fennic languages except Livonian ... Võru Estonian also has a passive: a transitive clause with the predicate verb in a personal form of the present or imperfect indicative can be made passive by transforming the object into a subject and replacing the active predicate verb with the corresponding passive verb (Viitso I998: II2).

The morphology volume of the authoritative Eesti keele grammatika (Erelt et al. 1995) recognizes a basic opposition in tegumood or geenus between personal verb forms and impersonal forms, which exist for each tense/ mood/aspect combination in Estonian. Erelt et al. (1995: 73) characterize the impersonal as encoding the involvement of an indefinite animate subject, which remains unspecified:

Impersonaal näitab, et tegevus lähtub indefiniitsest elus tegijast - umbisikust -, mis jääb lauses eksplitsiitselt väljendamata, s.t tegevussubjekt ei realiseeru alusena. ${ }^{10}$

Erelt et al. (1995: 73) illustrate this opposition by contrasting the personal forms kaklesid and sõidan in (7a) in (8a) with their impersonal counterparts kakeldi and sõidetakse in (7b) and (8b).

(7) (a) Poisid kaklesid õues.

boys fight.PAST.3PL outside

'The boys were fighting outside.'

(b) Õues kakeldi.

outside fight.PAST.IMP

'People were fighting outside.'

[9] In addition to the national languages Estonian and Finnish, the Balto-Finnic family comprises a number of smaller, and in many cases endangered, languages. These include Livonian, Karelian, Ingrian, Liivi, Ludian, Veps and Vod.

[Io] 'The impersonal indicates that an activity is performed by an indefinite animate actor (impersonal), which remains without explicit expression in the clause, i.e., the agent is not realized as the subject' [JPB]. 
(8) (a) Homme sõidan linna. tomorrow travel.PRES.ISG town.ILLA(TIVE)

'I will travel to town tomorrow.'

(b) Homme sõidetakse linna. tomorrow travel.PRES.IMP town.ILLA

'One is/They are travelling to town tomorrow.'

Other descriptions of Estonian apply the term 'passive' to the same class of forms, though the discussion of these forms, as well as the glosses assigned to them, bring out a personal/impersonal opposition. This opposition is clearly expressed in the descriptions of the 'passive' voice below:

In Estonian, the passive voice (umbisikuline tegumood) is an impersonal verb form. That is, the agent responsible for the action of the verb is usually unknown or generalized. It can be translated into English either by using the passive voice or the indefinite 'one' or 'they' (Tuldava 1994: 272).

In Estonian voice refers to whether the subject or agent of an action is known or unknown. If the subject is explicit in the context then personal forms of the verb are used. The impersonal forms are most similar to French on as in on chante (someone sings) or German man as in man singt (Mürk 1997: 2I).

The references to the indefinite personal pronouns 'one', 'they', man and on highlight the fact that the suppressed subject indicated by impersonal forms in Estonian is normally identified as human and not merely as animate. As Torn (2002: 95) notes, a sentence like (9a), which contains an impersonal form of HAUKuma 'to bark', 'cannot refer to a dog, only to humans'. Such sentences must therefore be interpreted metaphorically. Since non-animate verbs, like AEGUMA 'to expire', cannot be assigned a metaphorical interpretation, the impersonal forms in (9b) are unacceptable.

(9) (a) Õues haugutakse.

outside bark.PRES.IMP

'One barks outside.'

(b) *Aegutakse/aeguti.

(Torn 2002: 95) expire.PRES.IMP/PAST.IMP

'One expires/expired.'

Impersonals may, however, be formed from any unaccusative verb that can be construed as having a human subject. Example (IOa) contains impersonal forms of the canonically unaccusative motion verbs TULEMA 'to come' and MINEMA 'to go', while (Iob) exhibits an impersonal form of the copula.

(Io) (a) Tullakse ja minnakse. come.PRES.IMP and go.PRES.IMP

'They [People] come and go.' 
(b) Soomes ollakse nii tõsised.

Finland.INES be.IMP.PRES so serious.NOM.PL

'People in Finland are so serious.'

(Vihman 200I)

As Torn (2002) shows, impersonal forms of transitive unaccusative verbs, such as JÄÄMA 'to stay' or KAALUMA 'to weigh' are also possible, provided that they can be associated with a human subject.

(II) (a) Pärast reisi jäädakse hotelli.

after trip stay.PRES.IMP hotel.ILLA

'After the trip one stays at the hotel.'

(b) Pärast suurt söömist kaalutakse nii mõnigi kilo rohkem. after big eating weigh.PRES.IMP so several kilo more 'After a big feast, one weighs several kilos more.'

(Torn 2002: 96-97)

Unlike passives, the subject of an impersonal verb is not demoted, but merely unexpressed. This difference is not only reflected in the active interpretation of impersonals, but also in the fact that suppressed subjects may serve as antecedents for reflexive pronouns in examples like (I2a).

(I2) (a) Sooh, siis nüüd loetakse ja naerdakse

so, then now read.PRES.IMP and laugh.PRES.IMP

ennast segaseks.

self.PART muddled.TRAN

'So now one reads and laughs oneself silly.'

(Vihman 200I)

(b) Siin ehitatakse uut maja.

here build.PRES.IMP new.PART house.PART

'Here they are building a new house.'

(Tuldava 1994: 273)

Just as the suppressed subjects are not demoted, the objects of transitive verbs are not promoted. This is indicated by the fact that the reflexive pronoun in (I2a) and the object in (I2b) both occur in the partitive case, which here marks the 'partial object' of an uncompleted action.

Unlike canonical passive constructions, Estonian impersonals do not readily allow suppressed indefinite subject to be specified by an oblique agentive phrase, as Matthews (1955:370) notes:

the Estonian construction with poolt is not normally found associated with a passive verb, and the presence of the ergative syntagma with this postposition would be immediately felt as intrusive, because the Estonian verb is impersonal here. It is the impersonality of the Estonian passive verb which is its most characteristic feature.

Tuldava (I994: 273) concurs that the poolt-construction 'is not often used in Estonian'. However, he adds that '[o]ccasionally the postposition poolt "on the part of" is used to form a construction similar to the phrasing in English, with the agent in the genitive case', and cites the example in (I3). 


\section{(I3) Tartu ülikool asutati Gustav II Adolfi poolt. Tartu university found-PAST.IMP Gustav II Adolf.GEN by 'Tartu University was founded by Gustav II Adolf.'}

(Tuldava 1994: 273)

Matthews' claim that genitive 'poolt-phrases', though possible, are felt to be 'intrusive' is confirmed by Torn (2002: 93), who notes that native speakers tend to regard examples like (I3) as 'questionable', and by Nemvalts (I998: 63), who identifies 'poolt-phrases' as an Indo-European calque:

Passiivne poolt-tarind on üks indoeuropisme, mis üha rohkem ja rohkem laiutab ka kodumaises eesti keeles. ${ }^{11}$

\subsubsection{Finnish}

The cognate construction in Finnish introduces a number of confounding factors, including variation in the case marking of pronominal and nonpronominal arguments, and a general syncretism between impersonal and Ipl forms in spoken registers. Although some accounts classify this construction as a passive (e.g., Siewierska I985; Manninen \& Nelson 2002), it exhibits essentially the same sensitivity to human agency and the same insensitivity to argument structure as the Estonian impersonal. Descriptive and comparative grammars again emphasize the use of the impersonal form to suppress the syntactic realization of an animate or human subject:

There is also a subparadigm of impersonal inflection, used when the subject is unknown, or to avoid stating the subject (Abondolo I998: I7I).

The Finnish passive ... indicates that the action of the verb is performed by an unspecified person, i.e. that the agent is impersonal (indefinite). It thus roughly corresponds to ... German man, French on and English 'one' (Karlsson I999: I72).

It is not possible to speak about a passive voice in Finnish in the same sense as the English passive ... It would be better to speak of an indefinite verb category which resembles the passive in that it makes omission of the subject possible ... The passive is generally used to refer to a human agent, and sometimes also to other animate beings, which are not further specified in the linguistic structure. The object of a passive clause corresponds to the object of the active one (Sulkala \& Karjalainen I992: 288).

The Finnish impersonal shows formal as well as interpretive parallels with its Estonian counterpart. As Karlsson (I999: I72) notes, the impersonal 'occurs in all tenses (present, past, perfect and pluperfect) and also all moods

[II] 'The passive poolt-syntagma is one of the Indo-Europeanisms that increasingly is spreading more and more in the native [i.e., non-expatriate] Estonian language' [JPB]. 
(indicative, conditional, imperative and potential)'. As in Estonian, impersonal forms in Finnish do not show agreement with their suppressed subject. This failure of agreement is not only characteristic of synthetic impersonal forms, but also of periphrastic impersonal formations consisting of OLLA 'to be' and an impersonal past participle, as illustrated in (I4).

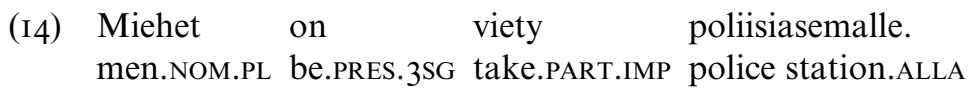

'The men have been taken to the police station.' (Shore I988: I58)

As in Estonian, the impersonal 'can be formed from both intransitive and transitive verbs' (Sulkala \& Karjalainen I992: 288), provided that the verbs select a human or animate agent. ${ }^{12}$ This pattern is illustrated by the examples in (15). Human agency is again explicit in the glosses, and in the interpretation that Shore (I988: I59) assigns to (I5a), stressing that 'the Agent responsible for the process is human; the indefinite would not be used if the house were destroyed in a bushfire or in a cyclone'. The impersonal form of OLLA in ( $15 \mathrm{~b}$ ) likewise indicates that unaccusatives that select human subjects can be freely impersonalized. Again as in Estonian, weather verbs and other non-transitive verbs do not have impersonal forms, but occur solely in the 3sg (Shore 1988: 156).
(a) Talo
tuhottin.
house.NOM destroy.PAST.IMP
(b) Suomessa ollaan niin totisia.
Finland.INES be.IMP.PRES so serious.NOM.PL
'In Finland, we/they/people are so serious.'

'The house was destroyed (by somebody or some people).'

(Shore 1988: I59)

The presence of a nominative argument in (I5a) is sometimes regarded as evidence for promotion. However, nominative is not exclusively a subject case in Balto-Finnic, and may also mark 'total' objects. ${ }^{13}$ In Finnish and Estonian, plural total objects occur in the nominative (whereas singulars occur in the genitive). In Estonian, total objects of impersonals (and all objects of imperatives) also occur in the nominative. Now since the argument talo is naturally interpreted as a total object in (I5a), it falls under the same generalization. To determine whether nominative is marking a derived subject or a total object in ( $15 \mathrm{a}$ ), it is useful to consider the impersonalization of verbs that select a partial object. In Finnish, as in Estonian, 'partial'

[I2] Though Shore (1988: I60) notes extensions of impersonals to apply to shrews and even enzymes in biology texts.

[13] The contrast between 'total' and 'partial' objects in Balto-Finnic is essentially a dependent-marking (Nichols 1986) strategy for distinguishing perfective from imperfective constructions. See Rajandi \& Metslang (1979) for discussion. 
objects generally occur in the partitive case. As the examples in (I6) show, the total object in (I6a) retains partitive case in the impersonal (I6b). ${ }^{14}$

(I6) (a) Konstaapeli vei miehiä poliisiasemalle. constable took men.PART police station.ALLA 'The/a constable was taking the men to the police station.'

(b) Miehiä vietiin poliisiasemalle. men.PART take.PAST.IMP police station.ALLA 'The men were being taken to the police station.'

(Shore 1988: 158)

Certain psychological and perception verbs also obligatorily govern 'partial' partitive objects in Finnish, as in Estonian (Tuldava 1994: 187). One such verb is RAKASTA 'to love' in (I7a). The corresponding impersonal form in (I7b) imposes the same object case demands on its argument.

(I7) (a) Tyttö rakastaa poikaa.

girl.NOM loves boy.PART

'The girl loves the boy.'

(b) Poikaa rakastettiin.

boy.PART love.PRES.IMP

'The boy is loved.'

(Östman I98I : 287)

The preservation of a partitive object case in these examples suggests that the argument of an impersonalized transitive verb remains a grammatical object. This conclusion is reinforced by the retention of accusative case on human pronouns in Finnish. As the examples in (I8) show, the 3sg pronoun hänet occurs in the accusative both when it functions as a direct object of a personal transitive in (I8a), and also when it functions as the argument of the impersonalized form in ( $\mathrm{I} 8 \mathrm{~b}$ ).

(I8) (a) Konstaapeli vei hänet poliisiasemalle. constable took s/he.ACC police station.ALLA

'The/a constable took him/her to the police station.'

(b) Hänet vietiin poliisiasemalle.

s/he.ACC take.PAST.IMP police station.ALLA

'S/he was taken to the police station.'

(Shore 1988: 157)

In sum, case and agreement patterns provide no more evidence of promotion in Finnish than in Estonian, just as the active indefinite interpretation again suggests that there has been no demotion.

\subsubsection{Summary}

Impersonalization in Estonian and Finnish is thus a relation-preserving operation with an insensitivity to argument structure and a sensitivity to

[I4] The examples from Shore (I988) and Östman (I98I) retain the original, albeit slightly misleading, sentence glosses. 
human agency. As with passives, it is important to distinguish the morphosyntactic properties that define impersonals from the semantic, functional and morphotactic traits that are merely characteristic of them. It is the integration of copulas and other unaccusative verbs, as well as the retention of direct objects, that fundamentally distinguishes Balto-Finnic impersonals from the passives in section 2.I above. These morphosyntactic properties are accompanied by an indefinite human interpretation, and a corresponding resistance to agentive phrases.

Yet, as noted in section 2.I.2, an indefinite human interpretation is not restricted to impersonals. Subjectless passives often have an implicitly human interpretation, which suggests that this interpretation is associated with subjectless forms of personal verbs, irrespective of the syntactic source of that subjectlessness. The human interpretation of subjectless passives may likewise degrade the acceptability of agentive phrases to the point that they are perceived 'not only as redundant, but almost as disruptive' (nicht nur als überflüssig, sondern geradezu als störend; Drozdowski 1995: 176), as the Duden observes with regard to the use of an agentive phrase with the subjectless getanzt 'danced'.

Furthermore, as poolt-expressions in Estonian illustrate, the use of agentive phrases need not be an all-or-nothing choice, even in indisputably impersonal constructions. Balto-Finnic impersonals clearly resist the use of an agentive phrase, as the explicit specification of an agent conflicts with their indefinite human interpretation. Nevertheless, as is often the case, Balto-Finnic languages have strategies for expressing agents in other constructions, and speakers may creatively extend these strategies to impersonals, particularly under the influence of contact with languages, such as German or English, whose personal passive constructions allow the use of agentive phrases.

In short, while the implication of human agency and a resistance to agentive phrases are strongly characteristic of impersonals, neither property is definitional. A subjectless passive can acquire an impersonal interpretation and a resistance to agentive phrases. Conversely, the interpretation of a suppressed subject can be generalized so that it acquires an 'indefinite agentive' or even merely 'indefinite' meaning. This semantic bleaching permits the use of agentive phrases to specify the suppressed subject further, and thereby shifts an impersonal construction into the semantic territory normally claimed by the passive. Constructions that combine the morphosyntax of impersonals with the morphosemantics of passives in this way, such as no/to forms in Ukrainian (Shevelov I963) or autonomous forms in Welsh (Morris Jones 1955), are particularly liable to be classified as passives. However, it is again important to bear in mind that this is a functional classification, which cuts across the basic morphosyntactic division between passive and impersonal constructions. 


\subsection{Deponent participles in Balto-Slavic}

An opposition between personal and impersonal voice is an areal feature of the Baltic region, which is also found in various of the neighboring Baltic and Slavic languages. ${ }^{15}$ Impersonal voice is expressed by no/to forms in a Sprachbund that covers Poland and the Ukraine and extends through the Baltics and along the northern Russian territories discussed in Timberlake I974, I976. $^{16}$ Yet whereas Estonian and Finnish contain impersonal forms for each tense/aspect/mood combination, Balto-Slavic verbs contain a single invariant form, which ends in -no or -to in Slavic and in -ma or -ta in Lithuanian. These forms show a formal affinity with passive participles, and while it is often assumed that they have evolved from neuter singular forms, it is also possible that they are conservative, preserving the voice-neutrality that Szemerényi (I990: 323) associates with to forms:

The suffix -to- is widespread in all I[ndo-]E[uropean] languages except Anatolian and Tocharian ... In the later history of the languages, there is a tendency to restrict the formation to passive use ... The original lack of voice differentiation is, however, quite clear ... in the Latin deponent the -to-formation regularly has active meaning, etc.

It is also possible that the impersonal character of no/to forms might be innovative in Slavic, while cognate forms in ma/ta are conservative in Lithuanian. However, for present purposes, the critical issue is the impersonal status of these forms and their dissociation from the passive system.

\subsection{Past active impersonals in Polish}

The no/to constructions in Polish are syntactically and semantically the closest counterparts of Balto-Finnic impersonals. Polish no/to forms exhibit a familiar sensitivity to human agency and an insensitivity to argument structure. In addition, these forms carry a definite past meaning that reflects their de-participial status. These characteristics are clearly specified in the descriptions below:

In contemporary Polish, clauses with the no/to participle ... are unanimously regarded by Polish linguists as active impersonal ... [with an] implied human subject [that] typically excludes the speaker (Siewierska I988: 27I).

The subject position is also eliminated in a second construction, which Polish shares only with Ukrainian. The construction is active (that is,

[15] The Baltic languages Lithuanian, Latvian and Old Prussian are often grouped with the Slavic languages to form a Balto-Slavic family, though nothing in the present account hinges on whether Balto-Slavic is a genetic or areal group.

[16] It is highly suggestive that many of the areas with impersonal no/to forms border on Uralicspeaking regions, and Veenker (I967) indeed argues that impersonal no/to constructions in North Russian reflect a Finno-Ugric influence. 
a direct object or other governed case is possible) even though the verbal form is related to the passive participle and the most natural English translation is usually a Passive construction ... Although not all verbs have this form, it occurs with many verbs that do not otherwise form a passive participle (for example, intransitive and 'reflexive' verbs). The construction has the value of past tense and the unspecified subject (singular or plural) is understood to be human and indefinite (Rothstein 1993: 713).

If the agent of an action is irrelevant ... the passive is often expressed with a past adjectival participle (passive) but in a special third person singular form ending in $-o$. This can be used with imperfective or perfective verbs, but only in the past tense (Bielec I998: 25).

The minimal pair in (I9) highlights the impersonal character of the no/to construction. The personal passive in (I9a) contains a nominative subject, gazeta, which agrees in gender and number with the auxiliary byla and the passive participle czytana. The demoted subject may likewise be realized as an oblique. In contrast, the no/to form czytano functions as a finite verb in (Igb) and may not combine with any form of the passive auxiliary BYć. The construction is interpreted as active and does not allow the suppressed agent to be expressed by an oblique phrase. Moreover, czytano remains transitive, and combines with a direct object, gazete, which does not trigger agreement. $^{17}$

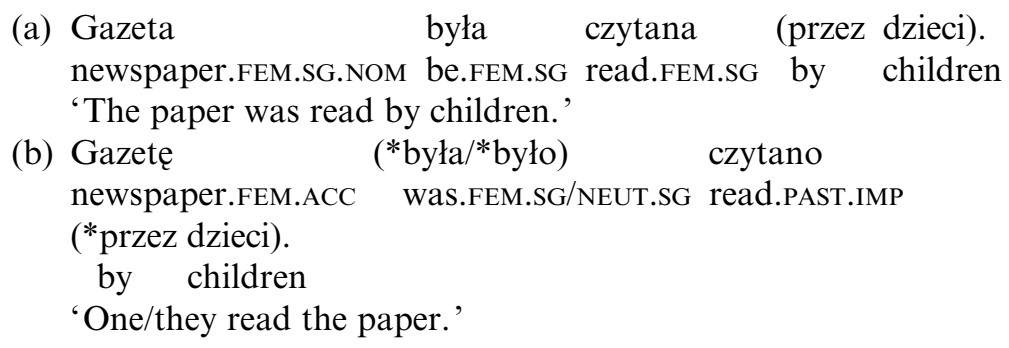

(b) Gazetę newspaper.FEM.ACC

(*przez dzieci).

by children

'One/they read the paper.'

The distributional and interpretive differences between passive participles and no/to impersonals are reinforced by a divergence in form, since neuter singular participles end in $-e$, not $-o$ in modern Polish. As in Balto-Finnic impersonals, the suppressed subject of a no/to verb may antecede a reflexive, as in (20a). Impersonal forms of unaccusative verbs are also possible, as (20b) shows. ${ }^{18}$

[I7] The object status of accusative gazete in (I9b) is confirmed by the fact that it alternates with genitive under negation.

[18] See also Kibort (2003) for a more comprehensive discussion of passive and impersonal constructions in Polish. 
(20) (a) Oglądano swoje zbiory.

looked-at.IMP REFL collections.ACC

'One looked at one's collection/They looked at their collection.'

(Kibort 200I: 167)

(b) Przeciętnie ważono 80 kilogramów.

on-average weighed.IMP $\{80$ kilograms $\}$.ACC

'On average, they weighed 80 kilograms.'

(Kibort 2000: 90)

\subsubsection{Impersonal no/to forms in Ukrainian}

The counterpart constructions in Ukrainian present an interesting generalization of the Polish pattern. Morphosyntactically, no/to forms in Ukrainian are impersonal, with suppressed subjects and structural accusative objects. These forms are, however, more participial in character and may combine with past auxiliaries. Moreover, no/to forms in Ukrainian pattern semantically with passives. They receive an indefinite, but not exclusively human or even agentive interpretation, which is compatible with the use of instrumental agentive phrases to further specify the suppressed subject.

The hybrid properties of no/to forms have led some analysts to treat them as a distinctive type of impersonal passive. A notable example is Sobin (1985), who represents the examples in (2I) as illustrating variation within the class of periphrastic passive constructions in Ukrainian.
(a) Cerkva
bula zbudovana v I640 roc'i (Lesevym). church.FEM.NOM was.FEM built.FEM.SG in I640 year Lesiv.INST 'The church was built in I640 by Lesiv.'
(b) Cerkvu (bulo) zbudovano v I640 roc'i (Lesevym). church.FEM.ACC was.NEUT built.IMP in I640 year Lesiv.INST 'There was built a church in 1640 by Lesiv.'

(Sobin 1985: 653-658)

In the personal passive in (2ra), the patient, cerkva, is realized as a nominative subject, which controls agreement on the auxiliary and participle. In the no/to construction in (2Ib), the subject again appears to be suppressed, but without concomitant promotion of the object. The participle zbudovano occurs in what Sobin (1985) glosses as the neuter singular, and retains an accusative object, cerkvu. Moreover, both constructions allow the agent to be realized as an instrumental oblique.

On the basis of this contrast, Sobin (1985) identifies subject demotion as the core property of passivization, and suggests that the promotion of structural non-subjects exhibits cross-linguistic variation. Although the first claim broadly accords with the position defended here, there are grounds for approaching the second conclusion with some caution. One question concerns the assumption that no/to forms are synchronically neuter singular participles. As Babby (1989) and Shevelov (1993) note in this context, neuter 
singulars again end in $-e$, not $-o$, in the modern language. Hence a personal passive with a neuter singular subject would contain a form like zbudovane in (22).

(22) Misto bulo zbudovane V I640 roc'i.
town.NEUT.NOM was.NEUT built.NEUT.SG in I640 year
'The city was founded in I640.'

Sobin is aware of this discrepancy, and presents two types of evidence to support the claim that no/to forms are neuter singular participles. The first is that no/to forms show the same stem alternations as personal participles. The second is that linguists, notably R. G. A. de Bray and W. K. Matthews, refer to no/to forms as neuter singular participles. Sobin (1985: 653-654) concludes by suggesting that 'it is much easier to maintain that there is such a neuter ending in - $o$ in agreement with a suppressed subject than that -no and -to are atomic and that the formal correspondences are accidents or relics'.

Yet the nomenclature adopted by historical linguists like de Bray and Matthews cannot be regarded as evidence of the synchronic status of no/to forms, given that they are working within a tradition that often uses terms like 'passive' to designate form classes. For example, in his discussion of the poolt-construction in section 2.2.I above, Matthews (I955:370) states that 'it is the impersonality of the Estonian passive verb which is its most characteristic feature'. Thus 'passive' is here the name of a verb form, which is morphosyntactically impersonal. The first of Sobin's points likewise relates to the morphotactic segmentation of no/to forms, and not to the morphosyntactic analysis of their parts. Any analysis that bases participial and no/to forms of ZBUDUVATI 'to build' on a common stem form zbudovan will capture stem alternations. However, the fact that zbudovano and zbudovana share a common stem zbudovan does not entail that they have a similar morphosyntactic analysis, but rather suggests that the distinctive properties of these forms are associated with their endings.

The central question thus concerns the status of the exponent $-o$. Now an invariant 'neuter singular ending' that does not agree with any neuter noun in Ukrainian cannot be said to have any genuine connection to the gender or agreement system of the language. To say that $-o$ is an exponent that can only enter into 'agreement with a suppressed subject' is merely an indirect way of identifying it as an impersonal marker, as Babby (1989: 19) argues. ${ }^{19}$ One could achieve the same effect by treating $-o$ as a 'fourth person' marker that can only agree with a suppressed fourth person subject, etc. Hence the apparent conflict with Sobin's classification is really more terminological than substantive.

[19] The development of a dedicated impersonal form in -o distinguishes Ukrainian and Polish from other Slavic languages, in which -o serves both to express neuter singular agreement and a lack of agreement (as it also does in Ukrainian bulo). 
An impersonal treatment of no/to forms likewise accords with the view of Shevelov (1963), who recognizes only a historical connection between no/to forms and the passive participial system:

The predicative form ending in -no, -to represents historically a fossilized, nominal form of the neuter gender of the passive past participle (Shevelov I963: I39).

Shevelov (1963) suggests that no/to forms originally had a past interpretation, and did not co-occur with auxiliaries or instrumental agents (like their modern Polish counterparts in section 2.3.I) ${ }^{20} \mathrm{He}$ identifies the residual formal resemblance to passive participles as the basis for the gradual introduction of past auxiliaries and instrumental agents. A possible reflex of the original interpretation is the fact that the past auxiliary bulo is optional with no/to forms, 'as it is felt to be superfluous' and, if present, 'may reflect a pluperfect sense' (Pugh \& Press 1999: 252). A second reflex is the fact that no/to forms are usually felt by speakers to be incompatible with the periphrastic future passive construction, consisting of a present form of BUTI 'to be' and a passive participle. Whereas the passive participle is fully acceptable in (23a), the no/to counterpart is much less acceptable in (23b). ${ }^{21}$
(a) Cerkva bude zbudovana.
church.FEM.NOM is.3SG built.FEM.SG
'The church will be built.'
(b) ?Cerkvu bude zbudovano. church.FEM.ACC is.3SG built.IMP
'There will be built a church.'

Alternatively, the anomaly of (23b) may, as Wieczorek (1994) suggests, be attributable to a conflict between the future tense of the construction and the perfective meaning of no/to forms (as well as, perhaps, to a residual prescriptive stigma). In either case, no/to forms in Ukrainian exhibit properties that strengthen their synchronic connection to the passive participle system. It is certainly possible that this connection could lead to a wholesale passive reinterpretation of no/to forms, particularly given the passive status of the cognate Russian forms. The fact that Ukrainian no/to forms cannot be based on unaccusative predicates, and do no allow reflexive pronouns, already distinguishes them from Polish cognates, as well as from impersonal constructions in Balto-Finnic. From a functional perspective it is probably accurate to regard no/to forms in Ukrainian as already semantically passive.

[20] The annotated bibliography in Billings \& Maling (1995a, b) provides a detailed chronology of these changes.

[2I] Though Billings \& Maling (1995b) cite examples of this construction from Wieczorek (1994: 30) and other sources. 
The basic challenge posed by Ukrainian no/to constructions derives from the fact that they retain the syntactic form of an impersonal construction, but have acquired a passive meaning. Thus, like their Polish cognates, no/to forms in Ukrainian can be analyzed as morphosyntactic impersonals, which suppress rather than delete their logical subject. Hence there is no advancement of logical objects, and no/to constructions retain direct objects in both languages. Yet whereas suppressed subjects receive an indefinite human interpretation in Polish, they are interpreted as indefinite in Ukrainian. This underspecified interpretation permits further elaboration by agentive phrases.

In contrast, a passive classification of no/to forms in Ukrainian leads to the recognition of an innovative 'transitive passive', in which the logical subject is eliminated, but eligible non-subjects somehow fail to advance and are realized as objects. The assumption that the advancement of non-subjects in passives is in some way 'optional' in transitive passives is of course incompatible with a promotional view of passives. But this assumption also sacrifices any kind of 'opportunistic' analysis, and makes advancement a property that must be stipulated on a construction-by-construction basis. ${ }^{22}$ One can avoid these complications, while preserving the intuition that underlies passive analyses, by treating no/to forms as morphosyntactic impersonals that convey a passive meaning, which is rather like the "passive meaning expressed by third-person plural verbs' (Wade 1992: 325).

\subsubsection{Voice and mood in Lithuanian}

The cognate malta forms in Lithuanian are neither morphosyntactically nor semantically passive, but just residually 'passive in form'. It is nevertheless worth reviewing the properties of these forms, as they have been widely represented as a type of passive. Like Polish and Ukrainian, modern Lithuanian does contain a genuine personal passive construction, which is illustrated in (24).

(24) (a) Tévas kviẽčia svečiùs.

father.NOM invites.3RD.PRES guests.MASC.PL.ACC

'Father invites guests.'

(b) Svečiaĩ yrà (tévo) kviečiamì.

guests.MASC.PL.NOM be.3RD.PRES father.GEN invited.MASC.PL.NOM

'Guests are invited by father.'

(Ambrazas 1997: 277)

Lithuanian also contains a class of subjectless $m a / t a$ forms which, like no/to forms in Polish and Ukrainian, may retain unpromoted accusative

[22] Though see Lavine (to appear) for an analysis in which subject advancement is keyed to agreement demands, so that the subjectlessness of no/to constructions is attributable to the fact that no/to forms do not impose agreement demands. 
objects. As in Balto-Finnic (and unlike Polish or Ukrainian), these arguments may also occur in the nominative, as the examples in (25) show.

(25) (a) Rãšoma láiškas/láišką.

write.IMP letter.NOM.SG/ACC.SG

'A letter is (being) written.'

(b) Per̃kama grūdaĩ/grúdus.

buy.IMP grain.NOM.PL/ACC.PL

'Grain is (being) bought.'

(Ambrazas 1997: 66I)

In his discussion of the contrast between (24) and (25), Ambrazas (1997: 663) notes that subjectless ma/ta constructions often receive the indefinite human interpretation characteristic of impersonals:

Passive constructions with a deleted agent are widely used to express an action with an indefinite, or generalized, or unknown, or irrelevant agent, instead of so-called indefinite-personal sentences with a zero subject, whose usage is rather restricted....

Moreover, $\mathrm{ma} / \mathrm{ta}$ forms also show the same insensitivity to argument structure as the canonical impersonals discussed in previous section. As Ambrazas (1997: 280) remarks, malta forms can be based on transitive unaccusative verbs that do not have personal passive forms:

The passive voice of some verbs governing the accusative object of quantity (kainúoti 'to cost', sver̂ti/svérti 'to weigh', trùkti 'to last', sukàti 'to turn (about age)') is formed with neuter passive participles [viz. ma/ta forms: JPB] only.

For example, sVEẽTI 'to weigh' has the ma/ta form sverriama in (26b), but no personal passive form.

(26) (a) Vištà svẽria dù kilogramùs.

hen.SG.NOM weigh.3RD.PRES two kilograms.PL.ACC

'The chicken weighs two kilograms.'

(b) Vištos svẽriama dù kilogrãmai/kilogramùs.

hen.SG.GEN weigh.IMP two kilograms.PL.NOM/PL.ACC

'The weight of the chicken is two kilograms.'

(Ambrazas 1997: 280-28I)

As the quotations from Ambrazas (1997) also indicate, malta forms are, like no/to forms in Polish and Ukrainian, frequently glossed as neuter passive participles. It is the 'passive' analysis of these forms that underlies the claim of Timberlake (1982) that Lithuanian allows 'unaccusative' and 'double' passives, in violation of the IAEX. The unaccusative pattern is illustrated in (27). 
(27) (a) Jìs bùvo kareĩvis.

he.MASC.SG.NOM be.3RD.PAST soldier.MASC.SG.NOM 'He was a soldier.'

(b) Jõ búta kareĩvio.

he.MASC.SG.GEN been.IMP soldier.MASC.SG.GEN '(They say) he was a soldier.'

(Ambrazas 1997: 662)

There is no denying that BÚTI 'to be' is a canonical unaccusative. However, it is another matter entirely whether the form $b \bar{u}^{\prime} t a$ in $(27 \mathrm{~b})$ is synchronically neuter or singular, much less passive. A neuter singular treatment of $\mathrm{ma} / \mathrm{ta}$ forms is again best regarded as a diachronic analysis, given that there is no productive neuter gender in modern Lithuanian, as Mathiassen (1996: 37) remarks:

Lithuanian distinguishes between two genders: the masculine and the feminine. To be exact, there are some marginal residuary forms reflecting the old neuter in impersonal constructions.

The presence of the agentive genitive $j \tilde{o}$ in $(27 \mathrm{~b})$ likewise provides no support for a passive analysis, given that the genitive cannot be omitted in this construction: ${ }^{23}$

The agentive genitive is obligatory in these sentences, which distinguishes them from other passive constructions (Ambrazas 1997: 662).

Descriptions, glosses and paraphrases of ma/ta constructions highlight a number of further respects in which they differ significantly from passives. The sentence glosses in (27) provide one indication, as they express no voice opposition between bút $a$ and the preterite bùvo. Instead, bút ta conveys a nonfactive or evidential mood in (27b). Another aspect of this mood contrast is elucidated by Dambriūnas et al. (I966: 662), who remark that (28a) 'has a more general meaning, while [28b] implies the surprise caused by the facts which only now were perceived'.

(28) (a) Kàs čià bùvo? who.NOM here be.3RD.PAST

(b) Kienõ čià búta? who.GEN here been.PASS.NEUT.SG 'Who was here?'

(Dambriūnas et al. 1966: 263)

Ambrazas (1997) summarizes the mood interpretations associated with malta forms as follows:

Passive constructions with the neuter participle and agentive genitive, especially without an auxiliary, are used in the evidential meaning

[23] It is likely that the genitive $j \tilde{o}$ is required to provide an agreement controller for the predicative complement kareĩvio. 
(of an action not observed directly, but inferred from its consequences, assumed or hearsay). In such cases, the agentive genitive is usually preposed to the verb, the word order of the respective active constructions being retained ... (Ambrazas 1997: 282).

Neuter passive participles with the preposed agentive genitive, especially when used without an auxiliary, can acquire the evidential meaning close to that of the indirect mood. It denotes an action inferred from its consequences or hearsay, or assumed, or an action causing surprise (Ambrazas 1997: 28I).

There is a simple explanation for this use of ma/ta forms. The evidential mood is principally expressed by using active participles without auxiliaries. However, present indicative forms of auxiliaries are frequently omitted anyway in periphrastic formations. The resulting ambiguity is resolved by the use of malta forms, as malta forms never occur in periphrastic indicatives.

The main formal difference between the oblique mood and the compound forms for the indicative mood is the obligatory absence of the auxiliary verb. But since the auxiliary verb of the present tense of the indicative mood is sometimes omitted, three forms of the oblique mood [viz. the past, past imperfect passive and past perfect passive: JPB] may formally coincide with those of the indicative mood and therefore they may become ambiguous (Ambrazas 1997: 284).

The evidential function of malta forms also accounts for their usage in examples like (29b).

(29) (a) Jìs

bùvo išẽjęs.

he.MASC.SG.NOM be.3RD.PAST left.MASC.SG.NOM

'He has gone out.'

(b) Jõ búta išeita.

him.MASC.SG.GEN been.IMP left.IMP

'(They say/Evidently) he has gone out.'

(Ambrazas 1997: 284)

Timberlake (1982) classifies (27b) as a 'double' passive, on the grounds that both the auxiliary and participle occur in the 'passive' form. At the very least, one could object that the notion of multiple passivization is misapplied here, as the formal similarity is plausibly regarded as concord. And as in previous examples, the glosses in (27) express a mood opposition rather than a voice contrast.

Moreover, the detailed discussion of these constructions in Ambrazas (1997) clarifies the function of mood concord in Lithuanian. The form búta is the sole exponent of evidential mood when, as in (27b), it takes a complement that lacks a ma/ta form. In periphrastic verbal constructions like (29), the concord between búta and the malta participle serves to reinforce an 
evidential interpretation:

If an active periphrastic verb form undergoes passivization (to express evidential meaning explicitly), both the auxiliary and the main verb assume the form of the passive neuter participle ... The active form of the auxiliary can be retained, but in this case the evidential meaning is less clear, cf.: Jõ bùvo išeita (Ambrazas I997: 283-284).

The morphosyntactic contrast in (29) thus again involves mood, not voice. The $\mathrm{ma} / \mathrm{ta}$ forms in (27b) and (29b) are subjectless participles that express evidential mood. Although the stem of these forms records a historical connection to the passive participle system, ma/ta form express no synchronic voice opposition. Hence the observation that $\mathrm{ma} / \mathrm{ta}$ constructions appear to contravene the IAEX does not bear in any way on the evaluation of universal claims about passive constructions. The passive in Lithuanian is represented solely by the personal pattern in (24b). This construction expresses a standard voice opposition, and is subject to familiar morphosyntactic constraints.

There is no need to interpret traditional descriptions of 'neuter passive' participles as endorsing the view that ma/ta forms are morphosyntactically passive. The idea of a 'passive' form of a non-transitive predicate is clearly incongruous with the use of 'passive' to designate a morphosyntactic class, but perfectly intelligible if 'passive' is being used to designate a form class. The reference in Ambrazas (I997: 284) to a form that 'undergoes passivization to express evidential meaning' indicates that the term 'passive' is being understood in this sense. This usage is reminiscent of the reference to 'the Estonian passive verb' in Matthews (1955: 370), and analogous to the use of terms like 'past' and 'present' to designate participles that are based on the same stem as a finite form or series.

It perhaps also worth clarifying that the impersonality of the Lithuanian malta form lies primarily in the lack of an agreeing subject. Hence it is possible to regard agentive genitives as non-canonical subjects of one sort or another. Matthews (I955: 356) classifies 'the neuter passive participle qualified by a genitive subject' as 'a formally possessive construction', an analysis that accounts both for the case of the argument and the lack of agreement. One could also analyze the agentive genitive in ma/ta constructions as a type of 'quirky' subject. The oblique case of these subjects could then be interpreted as a marker of mood subordination. Alternatively, Schmalstieg (I987) suggests that agentive genitives are a relic of an ancient ergative construction in Indo-European, while Lavine (2000) argues at some length that these arguments are morphologically ergative but function syntactically as subjects.

The present account is broadly compatible with these types of alternatives, since each of the analyses concedes the central claim that Lithuanian ma/ta forms are not morphosyntactically passive. 


\subsubsection{Summary}

The variation exhibited by no/to forms in Slavic and their ma/ta counterparts in Lithuanian underscores the value of distinguishing the morphosyntactic properties of a construction from associated morphosemantic and morphotactic traits. In standard Russian, a form such as čitanoe 'read' is synchronically a neuter singular passive participle. The cognate forms in Polish, Ukrainian and Lithuanian are, on the other hand, morphosyntactically impersonal, with more of a formal or semantic affinity to the passive system. Ukrainian no/to forms are passive in form and meaning, whereas Polish no/to forms and Lithuanian $\mathrm{ma} / \mathrm{ta}$ forms are merely passive in form.

\subsection{Autonomous forms in Celtic}

Differences between the properties of 'autonomous' forms in Celtic are in many ways reminiscent of variation within Balto-Slavic. Morris Jones (I955: 333) identifies autonomous forms as a reflex of an 'ending *- $r$ - [that] formed impersonals' in Proto-Indo-European and 'survived only in Indo-Iranian and Indo-Keltic'. Fife (1993: 15) likewise classifies each of the modern descendents as impersonal:

Another shared trait in the verbs is the presence in the paradigm of the 'impersonal' or 'autonomous' verb form. Basically, all Celtic languages possess an impersonal form for each tense which is neutral as to the person and number features of the subject... While this form can often be translated as a passive ... the ending also occurs with intransitive verbs as with Irish táthar 'they/people are' ... The actual usage of these forms has diverged significantly over time (in Welsh these have become rather literary constructions, but are everyday forms in Irish), but the presence of a special verbal inflection for an unspecified subject is another particular feature of Celtic.

Descriptions of autonomous forms in individual languages typically highlight the role of human agency, and an insensitivity to transitivity, which constrains the formation of passives. These properties are clearly stated in the following descriptions of Breton, Welsh and Irish:

BRETON: The impersonal forms in -er and -ed, typical of the Celtic languages, constitute a seventh form in the personal conjugation paradigm. They refer to a putative human subject whose identity one either does not wish to or is unable to specify. The meaning is thus very close to that of the French on 'one' (Hewitt 2002: 30).

WELSH: Each tense has in addition an impersonal form, whose implied indefinite subject means 'some one, some, they' Fr. 'on', Ger. 'man'; as $d y$ wedir 'they say, there is a saying, [Fr.] on dit' ... Intransitive verbs including the verb 'to be' are frequently used in the impersonal, and the 
forms are not felt to be in any way different from transitive impersonals except that a trans. verb requires an object (Morris Jones I955: 316-3I7).

WELSH: Although sometimes listed as 'passives', these two forms [in -ir and -wyd: JPB] are properly referred to as autonomous or impersonal, since they are not strictly speaking passive in sense (note that they can be formed for all verbs, including intransitives like come or $g o$ that have no passive) (King 2003: 224).

IRISH: The autonomous form of a verb expresses the verbal action only, without any mention of the agent (the subject), or any indication of person or number:

Briseadh an fhuinneog (The window was broken) (Christian Brothers I990: 94).

Like the impersonals considered above, autonomous constructions pattern syntactically with active clauses. In particular, autonomous forms of transitive verbs retain objects, which are realized by object pronouns in Breton (Hewitt 2002: 19), Welsh (Thorne 1993: 313) and Irish (Noonan I994: 285). Nouns in Breton and Welsh no longer inflect for case, and there is no distinctive accusative noun case in Irish. However, the object of a periphrastic verbal noun construction in Irish has the same case in transitive and autonomous clauses. For example, the object Thomáis in the transitive progressive in (30a), also occurs in the genitive in the corresponding autonomous progressive in (3ob).

(30) (a) Bhí Seosamh ag bualadh Thomáis.

was Joseph at hit.vN Thomas.gen

'Joseph was hitting Thomas.'

(b) Bhíothas ag bualadh Thomáis.

was.IMP at hit.vN Thomas.gen

'One/someone was hitting Thomas.'

(Noonan 1994: 289)

Autonomous forms can also be based on intransitive verbs, including unaccusatives. As in Balto-Finnic and Lithuanian, this possibility extends even to the verb 'be'. In (3ob), an autonomous form of the Irish verb Bí functions as an auxiliary, while in (3I), a different form functions as a main verb. Again as in Balto-Finnic, autonomous impersonals cannot be based on weather verbs, or on other types of non-transitive constructions with 'non-referential subjects' (Noonan I994: 289).

(3I) Táthar cairdiúil anseo.

is.IMP friendly here

'They/People are friendly here.'

(Noonan 1994: 288)

These properties support Fife's (1993) treatment of autonomous forms as impersonals. Their logical subjects are suppressed rather than deleted, 
and non-subjects may be realized as objects. As in Balto-Slavic, it is the interpretation of impersonal forms that shows the greatest variation. Autonomous forms in Breton pattern most closely with Balto-Finnic and Polish impersonals. As Hewitt (2002: 34) notes, 'Breton forms are fully active and impersonal, imply an indeterminate human subject, and do not allow human agent phrases'. Autonomous forms in Modern Welsh are more plausibly regarded as semantically passive and correspondingly, like Ukrainian, freely allow agentive phrases. The Irish forms fall somewhere in the middle. An indefinite human interpretation is suggested by the glosses of the examples in (30) and (3I), as well as by the consistent use of 'one' in the glosses that Ó Siadhail (1989: I80) assigns to autonomous forms. Stenson (1989) likewise suggests that agentive phrases are disallowed in Irish. However, Mac Eoin (I993: I26) asserts that 'the agent may be expressed by means of the preposition le "with", and Noonan (1994: 306) cites a number of examples, while conceding that 'they are, admittedly, rather rare'.

In short, while all of the modern autonomous forms are morphosyntactically impersonal, they differ in meaning, use and even register. Breton is clearly impersonal in meaning. Welsh is arguably passive in meaning, though, as Hewitt (2002: 17) stresses, it should be borne in mind that 'in Welsh, these forms are emphatically part of the literary register, and apart from a handful of set phrases, are rarely heard in spontaneous conversation'. The corresponding Irish forms pattern either more with Breton or with Welsh, depending on the dialectal splits adumbrated in Hewitt (2002: 32-34).

\subsection{Reflexive impersonals and impersonalized passives}

This section concludes with a brief survey of some additional patterns that reinforce the contrast between passives and impersonals drawn above. Within the class of what are commonly called 'reflexive passives', one finds familiar variation between morphosyntactically passive and impersonal constructions. ${ }^{24}$ In some languages, reflexive passives are genuinely passive, while in others historically reflexive constructions have evolved into impersonals. The first pattern is illustrated in standard Russian, in which the passivization of imperfective verbs is expressed by reflexive forms in -sja. These reflexive passives have the same morphosyntactic properties as the passive participles that are formed from perfective verbs in Russian. In particular, reflexive passives can only be based on transitive unergative verbs, such as STROIT' in (32), and do not retain accusative objects. Like participial passives, Russian reflexive passives are also semantically passive, as they do

[24] In addition, reflexive constructions are often associated with a 'middle' interpretation, in which there is no 'implication of the existence of an Agent' (Keenan 1985: 245). See also Klaiman (I99I) for an extended discussion of middle voice. 
not imply an indefinite human agent, and, correspondingly, freely allow agentive instrumentals.

$$
\begin{aligned}
& \text { Cerkov' stroitsja rabočimi. } \\
& \text { church.NOM build.REFL.3SG workers.INST } \\
& \text { 'The church is being built by workers.' }
\end{aligned}
$$

In short, the Russian reflexive passive is morphosyntactically passive and passive in meaning, but residually reflexive in form. Yet other reflexive forms exhibit consistently impersonal properties.

\subsection{Reflexive impersonals in Romance}

Ttalian si-constructions provide a clear illustration of a type of reflexive impersonal that recurs in the modern Romance languages. The description in Maiden \& Robustelli (2000) clearly associates one use of the clitic pronoun $s i$ with a characteristically impersonal interpretation:

A major use of the third person reflexive clitic pronoun si is to indicate that the subject of the verb is human, but without specifying the identity of the subject (p. I20).

They go on to identify a range of syntactic properties that are correlated with this interpretation:

But indefinite personal si has properties which distinguish it from the passive reflexive and from other types of reflexive construction. With passive si the object of a transitive verb becomes its subject, and the verb agrees in number and gender with that subject. Nowadays, the construction with indefinite personal si usually behaves in exactly the same way ... But occasionally indefinite personal si is treated as the subject of the verb, so that the noun remains the object and the verb agrees with subject $s i$ - which means that the verb has a third person singular form (p. I2I).

Note that in analytic tenses ... both the auxiliary and the past participle are either in the plural ... or the masculine singular ... The latter form cannot be interpreted as passive, but only as indefinite, and absence of number and gender agreement with the noun is the hallmark of indefinite personal, as opposed to passive, structures (pp. I22-I23).

Maiden \& Robustelli (2000) cite other respects in which si impersonals pattern with active transitive constructions. Since a si impersonal has a direct object, this object tends to occur in the usual postverbal position, if it is a full noun phrase, and is realized as a direct object clitic $(l o, l a, l i$ or $l e)$, if it is pronominal. The distribution of impersonal si likewise differs from passive $s i$ in modal constructions, in clitic sequences, and in a number of other environments. These contrasts lead Cinque (I988) to distinguish between 
a '[+argumental]' passive $s i$, which obeys standard constraints on passives, and an implicitly impersonal '[-argumental]' si, which does not.

\subsubsection{Reflexive impersonals in Slavic}

Historically reflexive formations have also evolved into impersonal constructions in modern Slavic languages. Polish again provides a clear illustration, as Rothstein (I993: 7I2) remarks:

The reflex of the Proto-Slavonic enclitic accusative reflexive pronoun (sie) serves to form verbs and verbal constructions that are traditionally called 'reflexive' ... Many of the resulting meanings are shared with the other Slavonic languages, but one is peculiar to Polish (and to some Croatian and Slovene dialects): the use of sie with a third person (neuter) verbal form to express a generalized human subject (like the French on or the German man) with the verb maintaining its normal (even accusative) government.

The example that Rothstein (I993) goes on to cite is repeated, with morpheme glosses, in (33a). The example in (33b) is likewise given by de Bray (1980: 305) to illustrate that 'a reflexive verb can be used impersonally, like the use of "one" in English and can then govern an object'.

(33) (a) $\mathrm{Tu}$ się pije wódkę.

here REFL drink.3SG vodka.ACC

'One drinks vodka here.'

(Rothstein 1993: 712)

(b) Sprzedaje się książki.

sold.3SG REFL books.ACC.PL

'Books are sold.'

(c) Przeciętnie ważyło się 8o kilogramów (*ludziom).

on-average weighed.NEUT REFL $\{80$ kilograms $\}$.ACC people.DAT

'On average, one weighed 80 kilograms.'

(Kibort 2000: 9I)

As Kibort (2000) shows, reflexive impersonals may be formed from unaccusative intransitives such as BYĆ in (36b) below, as well as from transitives, such as WAŻYĆ 'to weigh' in (33c). Like no/to forms, and unlike the Russian construction in (32), these reflexive impersonals disallow agentive obliques.

The 'Croatian and Slovene dialects' that Rothstein (1993: 7I2) refers to above present an intriguing variation on this pattern. Standard descriptions of South Slavonic languages tend to classify their reflexive constructions as a type of passive. Herrity (2000: I62) reports that in Slovene ' $[t]$ he passive is expressed by the use of the reflexive morpheme se with the active form of a transitive verb', adding that '[i]n these cases the subject is not indicated'. This pattern is illustrated by examples such as (34a), in which the argument knjiga is nominative, and the sentence gloss is passive. 
(34) (a) Knjíga se tíska.

book.NOM REFL print.PRES

'The book is being printed (i.e. is at press).' (Herrity 2000: I62)

(b) Knjīàga se pî̌se .

book.NOM REFL write.PRES

'The book is being written.'

(Browne 1993: 333)

Browne (1993: 333) notes that in Serbo-Croatian examples like (34b) ' $[\mathrm{t}]$ he clitic se indicating unspecified human subject can be used to form a quasi-passive (always without agent-phrase)'. However, Browne (1993: 333) also remarks that '[s]ome Western dialects and recent Croatian codifications can keep the underlying object in the accusative', as illustrated by knjïàgu in $(35 \mathrm{a})$.

(35) (a) Knjìgu se pîšē.

book.ACC REFL write.PRES

'The book is being written.'

(b) Íšče se mlâjšo žẹ́nsko.

(Browne 1993: 333)

seek.PRES REFL younger.ACC.SG woman.ACC.SG

'A younger woman is sought.'

(Priestly I993: 439)

Priestly (1993: 439) likewise notes that '[t]o express impersonal generalizations' in Slovene, ' $[t]$ he following alternative construction occurs: reflexive verb + object-ACC'. This alternative is shown in (35b), in which the accusative mlâjšo žénsko occurs in place of the standard nominative mlâjša žẹnska.

At the very least, reflexive impersonals reinforce the central role that morphosyntactic criteria must play in individuating constructions. Despite similarities in form and function, the broad class of 'reflexives' or 'reflexive passives' subsumes a number of distinct subconstructions, including a class of reflexive impersonals. The patterns in Slovene and Serbo-Croatian also suggest somewhat more far-reaching conclusions. The variation between standard and dialectal impersonals is reminiscent of the alternation between nominative and accusative in the Lithuanian examples in (25). These alternations reflect different strategies for assimilating impersonals to the case conventions of a language. By associating nominative with the argument of a transitive impersonal, it is possible to preserve the generalization that the least oblique structural argument of a verb occurs in the nominative. Yet by associating the argument with accusative, one can maintain the generalization that affected objects occur in the accusative. It is not possible to preserve both generalizations, and speakers apparently reach different conclusions about the best way to reconcile this conflict.

If this is an appropriate way to think about the variation in (34) and (35), it suggests that the nominative arguments in (34) are not true subjects, but counterparts of the nominative complements in Balto-Finnic. The fact 
that these arguments trigger subject agreement is inconclusive, given that nominative complements are known to control agreement, Icelandic providing a familiar case (Thráinsson 1979). The recognition of reflexive impersonals also bears on the role of agentive phrases in passives. Keenan (1985: 247) proposes that the status agentive phrases is an independent dimension of variation within the class of passives. The observation that 'reflexive passives' tend to resist agentive phrases is often taken as support for this view. There may indeed be a core of morphosyntactic passive constructions in which available strategies for expressing agentive phrases must be disallowed by fiat. Nevertheless, it is likely that the number of such cases will turn out to much smaller than usually believed, once reflexive impersonals (and middles) are correctly classified.

\subsubsection{Impersonalized periphrastic passives}

Polish reflexive impersonals interact with personal passives in a way that seems at first remarkable, but is in fact fully consistent with the properties of both constructions. As noted in section 2.3.I, Polish passives are periphrastic, consisting of a personal form of the auxiliary BYć (or zOSTAĆ), and the passive participle of a transitive verb. This pattern is illustrated by the example in $(36 a)$.
(36) (a) Piotr
był
bity
przez kaprala.
Peter.MASC.NOM was.MASC beaten.MASC.NOM by corporal 'Peter was beaten by the corporal.'
(b) Było się bitym przez kaprala.
waS.NEUT REFL beaten.MASC.INST by corporal
'One was beaten by the corporal.' (Avgustinova et al. 1999: I4)

As Avgustinova et al. (1999: 14) and Kibort (2000) observe, there is nothing to prevent the impersonalization of an auxiliary in a personal passive. This yields the example in (36b), in which the auxiliary takes the reflexive impersonal form bylo się, and the participle bitym occurs in the instrumental. The retention of an agentive phrase confirms the passive status of the participle in (36b), given that impersonals disallow agentive phrases in Polish. This also suggests the passive phrase bitym przez kaprala occurs within the larger impersonal construction defined by bylo się. However, the converse structure, in which an impersonal occurs within a larger passive construction, is not possible. Although there are impersonal no/to and reflexive forms of the transitive verb BIĆ 'to beat', these forms cannot occur embedded within a personal passive construction.

Noonan (1994) describes a similar interaction of passives and impersonals in Irish. Personal passives are periphrastic, consisting of an auxiliary and verbal noun, as illustrated in (37a). 


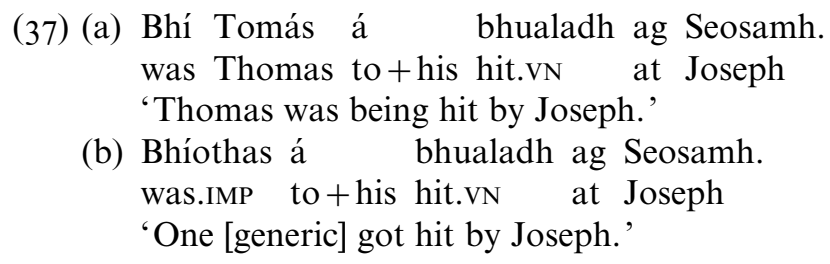

(37) (a) Bhí Tomás á bhualadh ag Seosamh.

was Thomas to + his hit.vN at Joseph

'Thomas was being hit by Joseph.'

(b) Bhíothas á bhualadh ag Seosamh.

was.IMP to + his hit.vN at Joseph
'One [generic] got hit by Joseph.'

(Noonan 1994: 289)

The impersonal of the passive in (37a) is given in $(37 b)$, with the active auxiliary bhi replaced by the autonomous form bhithas. There is again no means of forming the passive of an impersonal.

The development of a passive in Estonian permits a similar pattern. The innovative 'stative passive' in Estonian is, yet again, periphrastic, consisting of a form of the auxiliary olema and an adjectival -tud participle (Pihlak I993; Rajandi 1999). As (38a) indicates, this passive permits the agentive poolt-phrases that are incompatible with the impersonal constructions in section 2.2.I above.

(38) (a) Nad olid politsei poolt arreteeritud.
they.NOM were.3PL police.GEN by arrested
'They were arrested by the police.'
(b) Oldi politsei poolt arreteeritud.
be.IMP.PAST police.GEN by areteeritud
'One was arrested by the police.'

Torn (2002: 99) remarks that "it is possible to impersonalize the personal passive in cases where the "humanness" requirement is fulfilled", though she concurs with Mihkla \& Valmis (1979: 33), who characterize this construction as infrequent. As in the Polish and Irish examples above, the passive participle and agentive phrase in (38b) occur within a larger impersonal construction, marked by the impersonal auxiliary oldi. Once again, there is no strategy for forming passives of impersonals.

In sum, the interaction of passives and impersonals lends further support to the claim that they are separate morphosyntactic constructions. Personal passives can be impersonalized, since they are just derived intransitives (or transitives). Yet impersonals cannot be passivized, because impersonals are subjectless and thus do not satisfy the requirements of a subject-demoting passive rule.

\section{Diathesis as a morphological process}

The preceding section highlights basic differences between passive and impersonal constructions. Both constructions prevent the 'logical' subject of a predicate from being expressed as the syntactic subject, though they achieve this end in different ways. Passivization reduces the lexical valence of a predicate by deleting the logical subject. Passivization is thus intrinsically sensitive to the argument structure of its input and generally insensitive to 
human agency. The logical subject is said to be 'demoted', in the sense that the thematic role with which it is associated can only be expressed syntactically if a language allows that role to be realized as an oblique dependent. The apparent 'promotion' of initial non-subjects reflects a general constraint that identifies the highest eligible term in the argument structure of a predicate as the subject. A passivized predicate may then be subjectless if it contains no terms, or none that satisfy the conditions imposed on subjects at large.

Impersonalization, in contrast, is a valence-preserving operation that suppresses the syntactic realization of a subject. Impersonalized forms nevertheless preserve the lexical transitivity of their input and retain an unexpressed subject that characteristically determines an active indefinite interpretation and may even provide an antecedent for reflexive pronouns. Logical objects cannot advance to subject in a subjectless construction, and are realized as syntactic complements, sometimes bearing object cases, such as partitive or accusative. Since impersonalization merely determines a subjectless output, it is insensitive to the initial argument structure of an input verb. However, in languages that strongly associate an indefinite human interpretation with subjectless forms of personal verbs, subjectsuppression tends to be restricted to verbs whose subjects can be construed as human.

\section{I Argument structure}

The analyses presented below relate the distinctive properties of passive and impersonal constructions to the difference between subject deletion and subject suppression. The main prerequisite of this account is a model of grammatical description that supports a three-way contrast between thematic structure, lexical transitivity, and surface valency, as proposed by Avgustinova et al. (1999: 7) ${ }^{25}$ These notions are transparently represented in HPSG-style descriptions of the sort illustrated in (39).

$$
\left[\begin{array}{ll}
\text { SUBJ } & \text { list containing subject term } \\
\text { COMPS } & \text { list containing nonsubject terms } \\
\text { ARG-S } & \text { list containing term arguments } \\
\text { ROLES } & \text { list containing thematic roles }
\end{array}\right]
$$

The thematic structure of a predicate is represented by a list of thematic roles, which are assigned to a ROLEs attribute, as, for example, in Wechsler (1995). The relative order of semantic roles is standardly attributed to a

[25] Though their notion of 'argument structure' corresponds to what is here termed 'lexical transitivity'. 
general thematic hierarchy, in which an Agent role outranks an Experiencer role, which in turn outranks Patient, Theme and Goal roles, etc. The 'highest' roles of a predicate are canonically associated with 'subcategorized' arguments or terms, which correspond essentially to semantically unrestricted grammatical functions in LFG (Bresnan I982a, 200I), and to 'structurally' Case-marked elements in Chomsky (I98I). As in HPSG accounts (Manning \& Sag 1999), the lexical transitivity of a predicate is represented by the number of terms that are assigned to its ARG-S list. Thus an intransitive has a single term in its ARG-s list, a transitive has two terms, and a ditransitive has three.

The structures in (40) illustrate the correspondence between semantic roles and ARG-S terms. In the intransitive structure in (4Oa) there is one thematic role, $\theta_{1}$, which is associated, via the index ' $\mathrm{I}$ ', to the ARG-S term 1 . The transitive and ditransitive structures in (4ob) and (40c) again associate the highest role, $\theta_{1}$, to the first term, 1], and associate the roles $\theta_{2}$ and $\theta_{3}$ to the terms 2 and 3 .

$$
\text { (a) }\left[\begin{array}{ll}
\text { ARG-S } & \langle 1\rangle \\
\text { ROLES } & \left\langle\theta_{1}\right\rangle
\end{array}\right]
$$

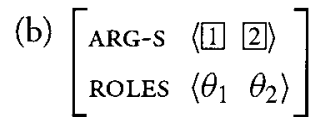

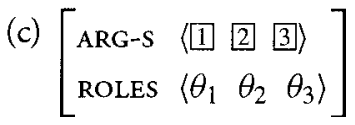

Although it might seem that thematic roles and ARG-S could be consolidated into a single representation, the properties of passives confirm the independence of thematic structure and lexical transitivity. Passivization detransitivizes a predicate by deleting one of its ARG-S terms, as in (4I). However, these passivized predicates are not semantically detransitivized, and retain the corresponding thematic role, $\theta_{1}$, which permits the logical subject to be realized as an agentive phrase.

$$
\text { (a) }\left[\begin{array}{ll}
\text { ARG-S } & \langle\rangle \\
\text { ROLES } & \left\langle\theta_{1}\right\rangle
\end{array}\right]
$$

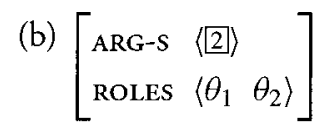

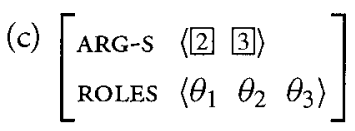

The surface valency of a predicate is determined by the association of ARG-S terms with grammatical relations. Given that passivization and impersonalization are both subject-sensitive processes, it will suffice to associate the 'highest' term with a distinguished SUBJ(ECT) relation, and treat all the remaining terms as COMP(LEMENT)S, as in HPSG. This is the effect of the mapping constraint in (42), which assigns the first term to the sUBJ list, and any remaining terms to the COMPs list.

\section{(42) Lexical Mapping Constraint (LMC)}

In a predicate with an ARG-S list $\mathbb{L}$, SUBJ $=\mathbb{L} \mid$ FIRST, and COMPS $=\mathbb{L} \mid$ REST.

The LMC exploits the fact that any list $\mathbb{L}$ can be divided into two parts: the

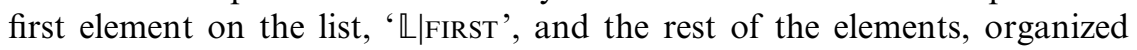


into a sublist ' $\mathbb{|} \mid$ REST'. The REST sublist can be similarly broken down into a FIRST element and REST sublist, and so on, until one reaches an empty sublist ' \langle\rangle ', which, by definition, has an empty list as its FIRST element and as its REST sublist.

Applied to the structures in (40), the LMC determines the patterns of surface valency in (43).

$$
\text { (a) }\left[\begin{array}{ll}
\text { SUBJ } & \langle[1\rangle \\
\text { COMPS } & \langle\rangle \\
\text { ARG-S } & \langle[1] \\
\text { ROLES } & \left\langle\theta_{1}\right\rangle
\end{array}\right]
$$

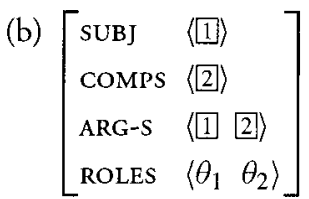

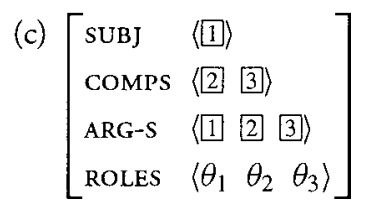

Although it might again seem possible to consolidate lexical transitivity and surface valency, the properties of impersonals confirm the independence of these notions. Thus the impersonal structures in (44) have the same the lexical transitivity as the active personal structures in (43), which distinguishes both from the passive structures in (4I). However, the impersonal structures in (44) are subjectless, which distinguishes their surface valency from that of the structures in (43).

$$
\text { (a) }\left[\begin{array}{ll}
\text { SUBJ } & \langle\rangle \\
\text { COMPS } & \langle\rangle \\
\text { ARG-S } & \langle\square\rangle \\
\text { ROLES } & \left\langle\theta_{1}\right\rangle
\end{array}\right]
$$

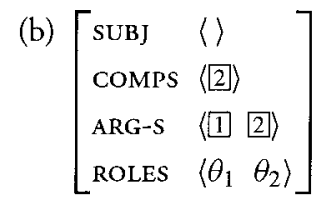

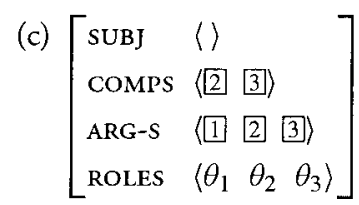

In short, the three-way contrast between active personal, passive and active impersonal 'voice' motivates a corresponding differentiation within lexical argument structure. It is far less important how precisely these notions are formalized, provided that they are independent. The present account expresses these notion in terms of the list-based notation of HPSG. However, a tripartite treatment of argument structure could also be incorporated into the LFG models of Lexical Mapping Theory developed in Bresnan \& Kanerva (1989) or Ackerman (1992), as is in fact proposed in Kibort (2003).

Moreover, a comparison of the structures in (43) and (44) suggests an interpretation of the LMC that preserves the spirit of the monotonic mapping constraints in LFG. The surface subjectlessness of the structures in (44) indicates that the LMC defers to the valence properties (here the empty list ' \langle\rangle ') introduced by impersonalization. That is, in much the same way that structural cases are interpreted as defaults that associate case values with elements that have not already been assigned lexically governed cases, the LMC can be construed as establishing a default valency mapping. 


\subsection{Morphotactic strata}

As the term 'surface valency' also suggests, the LMC need not be interpreted as applying to the basic entry of a predicate. Consequently, the RG notions of 'initial' and 'final' strata can be reconstructed in terms of the argument structures assigned to stems and words, respectively. Since nearly all contemporary approaches preserve a Bloomfieldian contrast between stems and words, initial subjects can be identified as stem-level subject terms, and final subjects as word-level subject terms. From this perspective, the Unaccusative Hypothesis of Perlmutter (I978) can be interpreted as a claim about variation in the argument structure of the stems of a language. Whereas the stems of unergative verbs will specify initial subject terms, the stems of unaccusative verbs will not.

The structures in (45) and (46) illustrate this contrast. The intransitive pair in (45a) exhibits the simplest unergative pattern. The single term in (45a) is assigned to the SUBJ list in the initial stem structure, annotated ' $\sigma$ ', and remains a subject in the final word structure, annotated ' $\omega$ '. Since there are no other terms, the final Comps list is empty. In (45b), the first term, 1, is again identified as the subject term in the initial and final structures, while 2 is assigned to the final comps list. ${ }^{26}$

\section{(45) Initial and final unergative argument structures}

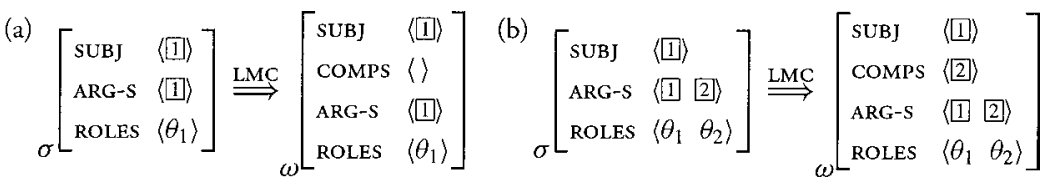

A comparison of the structures in (45) and (46) isolates the distinctive property of unaccusatives in this account. It is that the unaccusative stem strata in (46) do not identify any term as the subject.

\section{(46) Initial and final unaccusative argument structures}

(46) (a)

$$
\sigma\left[\begin{array}{ll}
\text { ARG-S } & \langle 11\rangle \\
\text { ROLES } & \left\langle\theta_{1}\right\rangle
\end{array}\right] \stackrel{\text { LMC }}{\Longrightarrow}\left[\begin{array}{ll}
\text { SUBJ } & \langle(1)\rangle \\
\operatorname{COMPS} & \langle\rangle \\
\text { ARG-S } & \langle 11\rangle \\
\text { ROLES } & \left\langle\theta_{1}\right\rangle
\end{array}\right]
$$

(b)

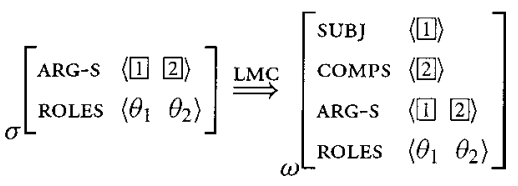

Applying the LMC to word-level entries in (45) and (46) neutralizes the initial contrast between unergative and accusative predicates. The LMC thus achieves an effect similar to that of subject-legislating constraints. As in

[26] One could also specify the second term, 2, as a complement term in the initial structure in (45). However, by leaving 2 initially unassociated, it is possible to avoid treating 'promoted' terms as complements at any level of analysis. 
LFG, 'advancement' in passives is attributable to the same constraint that identifies the highest term as a final subject in unaccusatives. There is no need for construction-specific advancement, nor for an analogue of the IAEX, which bars multiple advancements in RG. Yet the default status of the LMC preserves the subjectlessness determined by impersonalization.

\subsection{Morphosyntactic operations}

The model of argument structure outlined above permits a simple formulation of passive and impersonal operations. As in traditional approaches, a morphological operation, whether inflectional or derivational, is understood to apply to a lexical item, and not to a syntactic construction containing the item. More specifically, passivization and impersonalization are morphosyntactic operations, in the sense of Ackerman (I992) or Sadler \& Spencer (I998). Unlike morphosemantic operations like causativization (and perhaps middle formation), both passivization and impersonalization preserve the thematic structure of a predicate. The difference between passivization and impersonalization reflects a secondary division within the class of morphosyntactic operations. Passivization is a detransitivizing operation that deletes a subject term in the argument structure of a verb. Impersonalization, on the other hand, maintains the lexical transitivity of a verb, but assigns an empty suBJ value ' \langle\rangle ' that prevents any term from being associated with the subject function.

Since neither passivization nor impersonalization applies to non-transitive predicates, it will be useful to have a way of referring to non-empty lists. Expressions of the form ' $\langle 1|| X\rangle$ ' will be interpreted as denoting a list containing a non-empty FIRST element 1 and a (possibly empty) REST list $X$.

\subsection{Subject deletion}

Passivization can then be expressed, as in (47), as an operation that applies to a stem entry with a subject term 1 , and defines a detransitivized stem entry that lacks 1 . In effect, this rule defines a derived unaccusative stem. This stem is subject to the LMC, which remaps the highest remaining ARG-S term to the suBJ list, inducing the same 'advancement' as in the basic unaccusatives in (46).

(47) Passive Lexical Rule (PLR)

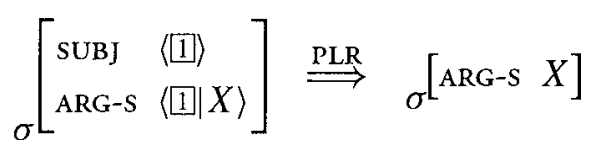

The structures in (48) show the derivation of passive forms. The first structure represents the properties of the basic stem of the German verb 
ABLEHNEN 'to reject'. The second stem structure exhibits the direct effect of passivization. The thematic roles are unaffected, but the highest term, 1, is deleted, along with the associated SUBJ value. Applying the LMC then determines the word structure in (48), in which the second term, 2, is assigned to the SUBJ feature.

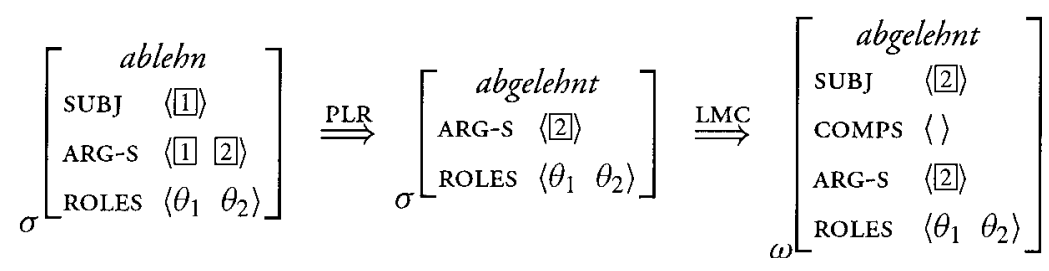

The resulting word entry is a derived intransitive that selects a nominative subject and no complement, as illustrated by the example in (2b). As in HPSG, the SUBJ and COMPS features in (48) determine the syntactic distribution of a predicate. The SUBJ term is matched against the subject argument in a syntactic representation, and COMPs terms are matched against syntactic complements. HPSG accounts also typically 'cancel' SUBJ and COMPS terms as they are matched against syntactic arguments, though nothing here depends on this assumption. The strategies for expressing oblique agents will tend to reflect the general treatment of optional dependents that are selected thematically, but not strictly subcategorized for. One possibility is that 'thematic selection' is a mode of combination that directly relates a thematic role of a predicate and a thematically compatible expression. This conception underlies the notion of 'thematic binding' developed in Grimshaw (I990). Alternatively, non-subcategorized elements could be assigned to a separate 'adjunct' valence list, or consolidated in a general list that also contains both adjuncts and subcategorized ARG-S terms. The DEPENDENTs list proposed in Bouma et al. (200I) can be interpreted in either of these ways.

The PLR has a similar effect on the unergative intransitive in (49). Passivizing the basic stem of the verb RAUCHEN again yields a detransitivized passive stem. Since there are no remaining terms, the LMC defines empty SUBJ and COMPs lists and the resulting word is subjectless. The non-transitive status of geraucht is reflected by the fact that it occurs with no arguments in (3b). Moreover, there is no discrete feature or element in this representation that determines its indefinite human interpretation, but rather the combination of an empty SUBJ list and an agentive thematic role.

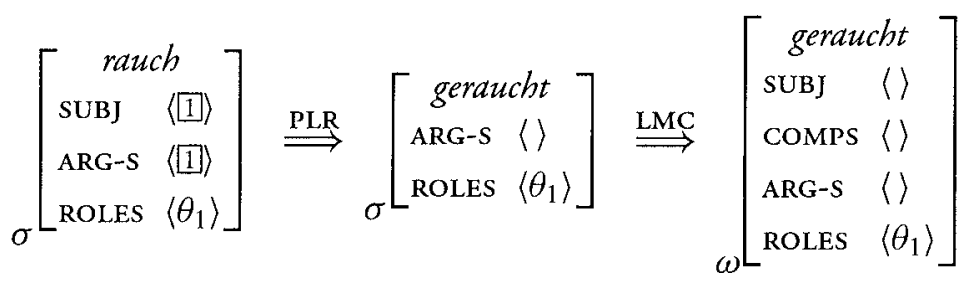


The PLR does not, however, apply to either of the unaccusative stems in (50). Since the stem entries for the transitive unaccusative DAUERN 'to last' and the intransitive BLEIBEN 'to remain' both lack an initial subject, the PLR does not apply to either. Hence there is no passive form of either verb, and the passive constructions in (5b) and (6b) are both unacceptable.

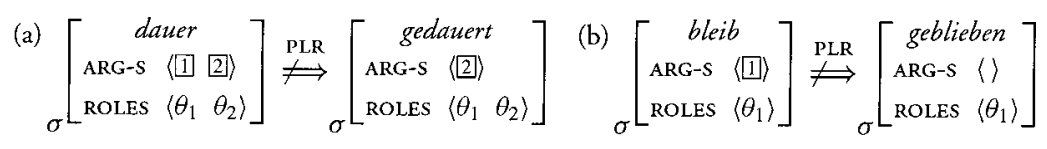

The difference between (48) and (49), on the one hand, and (50), on the other reflects the fact that passivization is intrinsically sensitive to the argument structure of an input stem. Passivization applies uniformly to unergative stems, and deletes their initial subject term, yielding a detransitivized output. If the initial argument structure contains additional terms that satisfy the conditions imposed on subjects at large, the LMC will assign a term to the suBJ list and define a personal passive. However, if the stem is initially intransitive, or if it contains only terms whose case or category properties violate the general conditions imposed on subjects, the passivized verb will be subjectless.

\subsubsection{Subject suppression}

In contrast, the effect of the impersonalization rule in (5I) is to define a subjectless output.

(5I) Impersonal Lexical Rule (ILR)

$$
\sigma\left[\operatorname { A R G - S } \left\langle[1|X\rangle] \stackrel{\text { ILR }}{\Longrightarrow} \quad\left[\begin{array}{ll}
\text { SUBJ } & \langle\rangle \\
\text { ARG-S } & \langle(1) \mid X\rangle
\end{array}\right]\right.\right.
$$

Impersonalization applies to a stem with at least one term, and assigns an empty SUBJ value that prevents any term from being realized as a syntactic subject. The process is illustrated in (52).

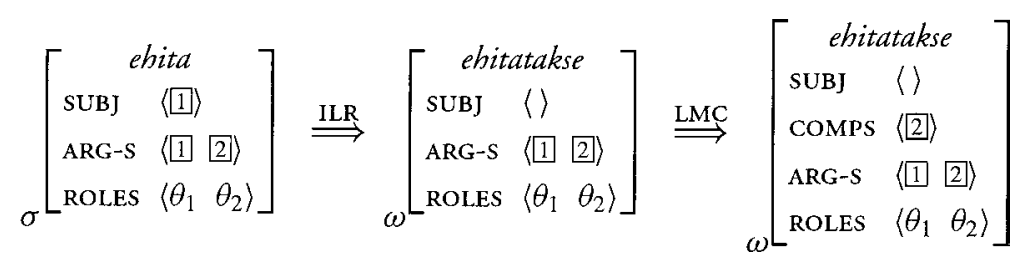

The initial subject of the stem ehita 'build' is removed from the suBJ list in the impersonalized word, but remains in the ARG-s list. The mapping 
constraint in (42) then applies to this structure, preserving the empty SUBJ value and assigning the second term to the comps list. The empty suBJ value in (52) prevents ehitatakse from combining with a syntactic subject, but does not detransitivize the verb. Hence the verb retains an ARG-s term which may serve as an antecedent for an anaphor, as in (I2a), while the combination of an agentive role and empty sUBJ implies an unspecified human subject. Moreover, the COMPs element may combine with a direct object. This possibility is illustrated in (I2b) above, in which ehitatakse occurs with the partitive object uut maja 'new house'.

Parallel remarks apply to intransitive unergatives like kakeldi 'fought' in (7b). The only difference is that impersonal forms of intransitives do not have a second ARG-S term and consequently do not take objects. The derivation of unaccusatives is similar. Suppressing the subject of an unaccusative like Estonian OLEMA 'to be' in (53) merely prevents the LMC from promoting the initial non-subject. The result is again a subjectless form that preserves the lexical transitivity of the basic stem entry.

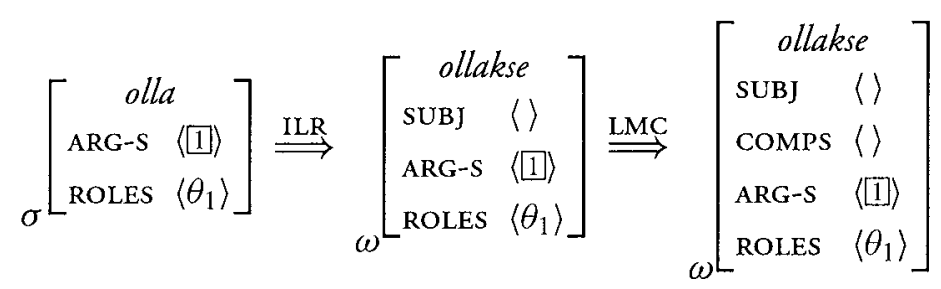

Transitive unaccusatives like KAALUMA 'to weigh' follow an analogous pattern, illustrated in (54). The subject remains empty, but the LMC identifies the non-empty sublist ' $\langle 2\rangle\rangle$ ' in as the comps value.

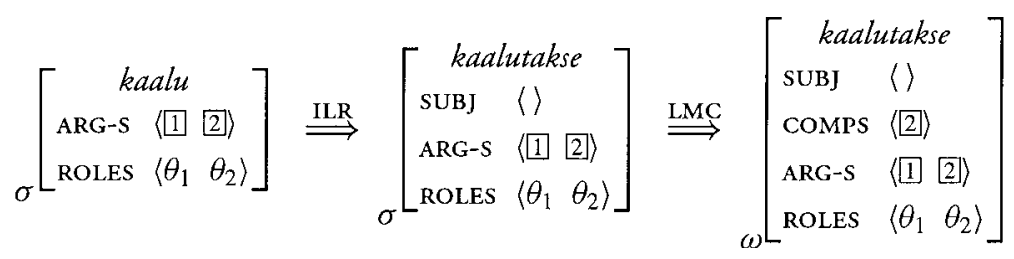

The fact that impersonalization may apply to unaccusatives permits the impersonalization of personal passives, which are, in effect, derived unaccusatives. Passivization of a transitive will yield a detransitivized unaccusative, which may, in principle, undergo impersonalization. The converse is, however, excluded, given that impersonalization yields a subjectless construction. The prerequisites of passivization are thus not met, since the impersonal obligatorily lacks the subject that the passive rule seeks to delete. Hence impersonals of passives are possible, but passives of impersonals are not. 


\section{Conclusion}

The analyses outlined above define passives and impersonals by means of morphosyntactic deletion and suppression operations. Yet the basic contrast is essentially theory-neutral, and compatible with any approach that can distinguish the lexical transitivity of a predicate from the selection of surface arguments. Passive verb forms are detransitivized, as assumed in traditional descriptions. Impersonal forms of personal verbs preserve lexical transitivity, but inhibit the expression of a syntactic subject. Since impersonalization merely suppresses the syntactic realization of a subject, it is generally insensitive to argument structure and applies equally to unaccusative and to unergative verbs.

More generally, distinguishing passive and impersonal constructions has a number of descriptive and theoretical consequences. On the descriptive side, this distinction contributes to a more accurate account of the construction inventory of various languages and language families, including Balto-Finnic, Balto-Slavic and Celtic, as argued above. On the theoretical side, reclassifying subjectless forms of unaccusative verbs as impersonals rehabilitates the RG claim that '[n]o impersonal Passive clause in any language can be based on an unaccusative predicate' (Perlmutter \& Postal I984a: 107). Restoring one of the few plausible morphosyntactic universals is perhaps worthwhile in itself.

Additionally, this insight can be incorporated, or reincorporated, into most syntactic approaches at no cost. Passives of unaccusatives are fully expendable in every account that allows them, since they are merely accommodated by generalized passive rules or constraints. The recognition of passives of unaccusatives in LFG, for example, does not reflect any deep formal or empirical principle, but is solely a consequence of formulating the passive rule so that it targets 'the most prominent semantic role of a predicator' (Bresnan 200I: 307), rather than 'the subject function' (Bresnan I982b: 9).

Returning to the traditional view of the passive as a subject-sensitive process is also compatible with a wide range of accounts, including the categorial analyses of Bach (1980) and Keenan (1985), which map predicates onto predicates, and transformational approaches, such as Baker et al. (1989). There is an even broader consensus that a detransitivizing morphological process plays a key instigating role in passive alternations; the main disagreements concern the syntactic reflexes of this process.

Finally, a morpholexical treatment of verbal diathesis also suggests the outline of a strategy for consolidating a number of different approaches. Recasting RG analyses in morphological terms not only reconciles a relational perspective with traditional views of voice alternations, but also allows key insights of RG accounts to be integrated into constraint-based models. Arguably the central differences between RG accounts and those developed in GPSG, LFG or HPSG derive from the RG claim that relational 
strata are syntactic representations. However there is no compelling reason to assume that strata - or entire relational networks, for that matter - are syntactic, rather than lexical. Strata provide an almost 'pure' expression of lexical valence, with practically no representation of any aspect of morphological form, constituent order or hierarchical structure. A morphological interpretation of strata accounts for the abstractness of RG analyses, since properties like order and arrangement are not represented in argument structures. The lack of a morphological component within RG also follows if $\mathrm{RG}$ is reinterpreted in toto as a theory of morpholexical alternations.

\section{REFERENCES}

Abondolo, D. (1998). Finnish. In Abondolo (ed.). I49-I83.

Abondolo, D. (ed.) (1998). The Uralic languages. London: Routledge.

Ackerman, F. (1992). Complex predicates and morpholexical relatedness: locative inversion in Hungarian. In Sag, I. A. \& Szabolcsi, A. (eds.), Lexical matters. Stanford: CSLI. 55-83.

Ambrazas, V. (ed.) (1997). Lithuanian grammar. Vilnius: Baltos Lankos.

Avgustinova, T., Skut, W. \& Uszkoreit, H. (I999). Typological similarities in HPSG: a case study on Slavic verb diathesis. In Borsley, R. D. \& Przepiórkowski, A. (eds.), Slavic in Head-driven Phrase Structure Grammar. Stanford: CSLI. I-28.

Babby, L. H. (1989). Subjectlessness, external subcategorization and the projection principle. Zbornik za Filologiju $i$ Linguvistiku 32(2). 7-40. [To be reprinted in Journal of Slavic Linguistics I0.]

Bach, E. (1980). In defense of passive. Linguistics and Philosophy 3. 297-34I.

Baker, M., Johnson, K. \& Roberts, I. (I989). Passive arguments raised. Linguistic Inquiry 20. 2I9-25I.

Ball, M. J. \& Fife, J. (eds.) (1993). The Celtic languages. London: Routledge.

Bielec, D. (1998). Polish: an essential grammar. London: Routledge.

Billings, L. \& Maling, J. (I995a). Accusative-assigning participial -no/to constructions in Ukrainian, Polish and neighboring languages: an annotated bibliography. Part I (A-M). Journal of Slavic Linguistics 3(I). I77-2I7.

Billings, L. \& Maling, J. (I995b). Accusative-assigning participial -no/to constructions in Ukrainian, Polish and neighboring languages: an annotated bibliography. Part 2 (N-Z). Journal of Slavic Linguistics 3(2). 396-430.

Bouma, G., Malouf, R. \& Sag, I. A. (200I). Satisfying constraints on extraction and adjunction. Natural Language \& Linguistic Theory 19. I-65.

de Bray, R. G. A. (1980). Guide to the West Slavonic languages: part 2. Columbus: Slavica.

Bresnan, J. (1982a). Control and complementation. Linguistic Inquiry I3(3). 343-434.

Bresnan, J. (1982b). The passive in lexical theory. In Bresnan, J. (ed.), The mental representation of grammatical relations. Cambridge, MA: MIT Press. 3-86.

Bresnan, J. (200I). Lexical-functional syntax. Oxford: Blackwell.

Bresnan, J. \& Kanerva, J. M. (1989). Locative inversion in Chichewa: a case study in factorization in grammar. Linguistic Inquiry $\mathbf{2 0}(\mathbf{I})$. $\mathrm{I}-50$.

Browne, W. (1993). Serbo-Croat. In Comrie \& Corbett (eds.), 306-387.

Burzio, L. (1986). Italian syntax. Dordrecht: Reidel.

Chomsky, N. (I98I). Lectures on government and binding. Dordrecht: Foris.

Chomsky, N. (1982). Some concepts and consequences of the theory of government and binding. Cambridge, MA: MIT Press.

Christian Brothers, T. (1990). New Irish grammar. Dublin: CJ Fallon.

Cinque, G. (1988). On si constructions and the theory of arb. Linguistic Inquiry 19(4). $52 \mathrm{I}-58 \mathrm{I}$.

Comrie, B. (1977). In defense of spontaneous demotion: the impersonal passive. In Cole, P. \& Sadock, J. M. (eds.), Grammatical relations (Syntax and semantics 8). New York: Academic Press. $47-58$. 


\section{J. P. B LEVINS}

Comrie, B. \& Corbett, G. G. (eds.) (1993). The Slavonic languages. London: Routledge.

Dambriūnas, L., Klimas, A. \& Schmalstieg, W. R. (1966). Introduction to Modern Lithuanian. Brooklyn, NY: Franciscan Fathers.

Drozdowski, G. (ed.) (1995). Grammatik der deutschen gegenwartsprache. Mannheim: Dudenverlag.

Durrell, M. (1996). Hammer's German grammar and usage. London: Arnold.

Erelt, M., Kasik, R., Metslang, H., Rajandi, H., Ross, K., Saari, H., Tael, K. \& Vare, S. (1995). Eesti keele grammatika, vol. I: Morfoloogia. Tallinn: Eesti Teaduste Akadeemia Eesti Keele Instituut.

Fife, J. (I993). Historical aspects: Introduction. In Ball \& Fife (eds.), 3-25.

Gildersleeve, B. L. \& Lodge, G. (I895). Gildersleeve's Latin grammar. New York: Macmillan \& Co. [Reprinted by Bolchazy-Carducci Publishers, Inc., 2000.]

Grimshaw, J. (1990). Argument structure. Cambridge, MA: MIT Press.

Herrity, P. (2000). Slovene: a comprehensive grammar. London: Routledge.

Hewitt, S. (2002). The impersonal in Breton. Journal of Celtic Linguistics 7. I-39.

Karlsson, F. (1999). Finnish: an essential grammar. London: Routledge.

Keenan, E. L. (1985). Passive in the world's languages. In Shopen, T. (ed.), Language typology and syntactic description, vol. I: Clause structure. Cambridge: Cambridge University Press. 243-28I.

Kibort, A. (2000). Morpholexical rules in Polish. In Bański, P. \& Przepiórkowski, A. (eds.), GLiPI: proceedings of Generative Linguistics in Poland. Warsaw: Polish Academy of Sciences. $82-93$.

Kibort, A. (200I). The Polish passive and impersonal in Lexical Mapping Theory. In Butt, M. \& Holloway King, T. (eds.), Proceedings of the LFGoI conference. Stanford: CSLI. I63-I83. (Proceedings available at http://csli-publications.stanford.edu/LFG/6/ lfgor.html)

Kibort, A. (2003). Passive and passive-like constructions in English and Polish: a contrastive study with particular reference to impersonal constructions. Ph.D. dissertation, University of Cambridge.

King, G. (2003). Modern Welsh: a comprehensive grammar. London: Routledge.

Klaiman, M. H. (I99I). Grammatical voice (Cambridge Studies in Linguistics 59). Cambridge: Cambridge University Press.

Lavine, J. E. (2000). Topics in the syntax of nonagreeing predicates in Slavic. Ph.D. dissertation, Princeton University.

Lavine, J. E. (to appear). The morphosyntax of Polish and Ukrainian -no/-to. Journal of Slavic Linguistics $\mathbf{I I}(\mathbf{2})$.

Mac Eoin, G. (I993). Irish. In Ball \& Fife (I993). IOI-I44.

Maiden, M. \& Robustelli, C. (2000). A reference grammar of Modern Italian. London: Arnold.

Manninen, S. \& Nelson, D. (2002). The Finnish passive is really a passive. Paper presented at LAGB Meeting, Manchester.

Manning, C. D. \& Sag, I. A. (1999). Dissociations between argument structure and grammatical relations. In Webelhuth, G., Koenig, J.-P. \& Kathol, A. (eds.), Lexical and constructional aspects of linguistic explanation. Stanford: CSLI. 63-78.

Mathiassen, T. (1996). A short grammar of Lithuanian. Columbus: Slavica.

Matthews, P. H. (I99I). Morphology. Cambridge: Cambridge University Press.

Matthews, W. K. (1955). Lithuanian constructions with neuter passive participles. The Slavonic and East European Review 33(8I). 350-37I.

Mihkla, K. \& Valmis, A. (1979). Eesti keele süntaks: kõrgkoolidele. Tallinn: Valgus.

Morris Jones, J. (1955). A Welsh grammar, historical and comparative: Phonology and accidence. Oxford: Clarendon Press.

Mürk, H. W. (1997). A handbook of Estonian: nouns, adjectives and verbs (Indiana University Uralic and Altaic Series I63). Bloomington: Indiana University.

Nemvalts, P. (1998). Kas väliseesti keeles on märgata süntaktilist omapära? In Lindström, L. (ed.), Väliseestlaste keelest. Tartu: Tartu Ülikooli Kirjastuse trükikoda. 55-66.

Nerbonne, J. A. (1982). Some passives not characterized by universal rules: subjectless impersonals. In Joseph, B. D. (ed.), Grammatical relations and Relational Grammar (Working Papers in Linguistics 26). Columbus: Ohio State University. 59-92.

Nichols, J. (I986). Head-marking and dependent-marking grammar. Language 62. 56-II9. 


\section{PASSIVES AND IMPERSONALS}

Noonan, M. (1994). A tale of two passives in Irish. In Fox, B. \& Hopper, P. J. (eds.), Voice: form and function. Amsterdam: Benjamins. 275-3II.

Ó Siadhail, M. (1989). Modern Irish: grammatical structure and dialectal variation. Cambridge: Cambridge University Press.

Östman, J.-O. (I98I). The Finnish 'passive' and Relational Grammar. In Hendrick, R. A., Masek, C. S. \& Miller, M. F. (eds.), Papers from the I7th Regional Meeting of the Chicago Linguistic Society. Chicago. 286-294.

Perlmutter, D. M. (1978). Impersonal passives and the Unaccusative Hypothesis. In Jaeger, J., Woodbury, A., Ackerman, F., Chiareno, C., Gensler, O. D., Kingston, J., Sweetser, E. E., Thompson, H. \& Whistler, K. W. (eds.), Proceedings of the Fourth Annual Meeting of the Berkeley Linguistics Society. I57-I89.

Perlmutter, D. M. (ed.) (1983). Studies in Relational Grammar I. Chicago: University of Chicago Press.

Perlmutter, D. M. \& Postal, P. M. (I983a). The Relational Succession Law. In Perlmutter (ed.), $30-80$.

Perlmutter, D. M. \& Postal, P. M. (I983b). Some proposed laws of basic clause structure. In Perlmutter (ed.), 8I-I28.

Perlmutter, D. M. \& Postal, P. M. (I984a). The I-Advancement Exclusiveness Law. In Perlmutter \& Rosen (eds.), 8I-I25.

Perlmutter, D. M. \& Postal, P. M. (1984b). Impersonal passives and some relational laws. In Perlmutter \& Rosen (eds.), I26-I70.

Perlmutter, D. M. \& Rosen, C. G. (eds.) (1984). Studies in Relational Grammar 2. Chicago: University of Chicago Press.

Pihlak, A. (1993). A comparative study of voice in Estonian. Tallinn: Eesti Sisekaitse Akadeemia Toimetised.

Priestly, T. M. S. (I993). Slovene. In Comrie \& Corbett (eds.), 388-45I.

Pugh, S. M. \& Press, I. (1999). Ukrainian: a comprehensive grammar. London: Routledge.

Rajandi, H. (1999). Eesti impersonaali ja passiivi süntaks. Tallinn: Eesti Keele Instituut.

Rajandi, H. \& Metslang, H. (1979). Määramata ja määratud objekt. Tallinn: Eesti NSV Teaduste Akadeemia Keele ja Kirjanduse Instituut.

Rothstein, R. A. (1993). Polish. In Comrie \& Corbett (eds.), 666-758.

Sadler, L. \& Spencer, A. (1998). Morphology and argument structure. In Spencer, A. \& Zwicky, A. M. (eds.), Handbook of morphology. Oxford: Blackwell. 206-236.

Schmalstieg, W. R. (1987). A Lithuanian historical syntax. Columbus, OH: Slavica.

Shevelov, G. Y. (1963). The syntax of Modern Literary Ukrainian. The Hague: Mouton.

Shevelov, G. Y. (1993). Ukrainian. In Comrie \& Corbett (eds.), 947-998.

Shore, S. (I988). On the so-called Finnish passive. Word 39(3). I5I-I76.

Siewierska, A. (1985). Passive: a cross-linguistic study. London: Croom Helm.

Siewierska, A. (1988). The passive in Slavic. In Shibatani, M. (ed.), Passive and voice. Amsterdam: Benjamins. 243-289.

Sobin, N. (1985). Case assignment in Ukrainian morphological passive constructions. Linguistic Inquiry I6. 649-662.

Stenson, N. (1989). Irish autonomous impersonals. Natural Language \& Linguistic Theory 7. 379-406.

Sulkala, H. \& Karjalainen, M. (1992). Finnish. London: Routledge.

Szemerényi, O. J. (1990). Introduction to Indo-European linguistics. Oxford University Press.

Thorne, D. A. (1993). A comprehensive Welsh grammar. Oxford: Blackwell.

Thráinsson, H. (I979). Complementation in Icelandic. New York: Garland.

Timberlake, A. (1974). The nominative object in Slavic, Baltic, and West Finnic (Slavistische Beiträge 82). Munich: Sagner.

Timberlake, A. (1976). Subject properties in the North Russian passive. In Li, C. (ed.), Subject and topic. New York: Academic Press. 547-570.

Timberlake, A. (I982). The impersonal passive in Lithuanian. In Macaulay, M., Gensler, O. D., Brugman, C., Civkulis, I., Dahlstrom, A., Krile, K. \& Sturm, R. (eds.), Proceedings of the Eighth Annual Meeting of the Berkeley Linguistics Society. 508-524.

Tommola, H. (1997). O supressive i ob ambipersonale. In Kudrjavcev, J. \& Kjul'moja, I. (eds.), Trudy po russkoj i slavjanskoj filologii (Lingvistika, novaja serija I). Tartu: Tartu Ülikooli Kirjastus. $173-187$. 


\section{J. P. B LEVINS}

Torn, R. (2002). The status of the passive in English and Estonian. In Hendriks, H. (ed.), Working Papers in English and Applied Linguistics 7. 8I-I06. Cambridge: Research Centre for English and Applied Linguistics.

Tuldava, J. (1994). Estonian textbook (Indiana University Uralic and Altaic Series I59). Bloomington: Indiana University.

Veenker, W. (1967). Die Frage des finnougrischen Substrats in der russischen Sprache (Indiana University Uralic and Altaic Series 82). Bloomington: Indiana University.

Vihman, V.-A. (200I). Nothing personal: some detransitivizing devices in Estonian. In Proceedings of the 200I Theoretical \& Applied Linguistics Postgraduate Conference. University of Edinburgh. (Proceedings available at http://www.ling.ed.ac.uk/ pgc/archive/200I/ proceedor.html)

Viitso, T.-R. (1998). Fennic. In Abondolo (ed.). 96-II4.

Wade, T. (I992). A comprehensive Russian grammar. Oxford: Blackwell.

Wechsler, S. (1995). The semantic basis of argument structure. Stanford: CSLI.

Wieczorek, D. (1994). Ukrainskij pierfiekt na -no, -to na fonie polskogo pierfiekta (Slavica Wratislaviensia 83). Wrocław: Wydawnictwo Uniwersytetu Wrocławskiego.

Author's address: Research Centre for English and Applied Linguistics, University of Cambridge, Keynes House, Trumpington St., Cambridge CB2 IQA, U.K.

E-mail:jpb39@cam.ac.uk 